JGR Oceans

\author{
RESEARCH ARTICLE \\ 10.1029/2018JC014458 \\ Key Points: \\ - We observed high chlorophyll $a$ and \\ macronutrient concentrations \\ co-occurring at the bottom of \\ Antarctic land-fast sea ice in late \\ spring \\ - Remineralization processes and \\ adsorption within sea ice best \\ explain the required sources of \\ nitrate and nitrite, phosphate, and \\ ammonium \\ - Biogeochemical modeling suggests \\ that sea-ice diatoms have a lower \\ affinity for silicic acid than pelagic \\ diatoms
}

Supporting Information:

- Supporting Information S1

Correspondence to:

S. M. Lim,

smlim@stanford.edu

Citation:

Lim, S. M., Moreau, S., Vancoppenolle, M., Deman, F., Roukaerts, A., Meiners, K. M., et al. (2019). Field observations and physical-biogeochemical modeling suggest low silicon affinity for Antarctic fast ice diatoms. Journal of Geophysical Research: Oceans, 124, 7837-7853. https://doi.org/10.1029/2018JC014458

Received 13 AUG 2018 Accepted 30 AUG 2019 Accepted article online 6 SEP 2019 Published online 17 NOV 2019

(C)2019. American Geophysical Union. All Rights Reserved.

\section{Field Observations and Physical-Biogeochemical Modeling Suggest Low Silicon Affinity for Antarctic Fast Ice Diatoms}

\author{
S. M. Lim $^{1,2,3}$ (D) S. Moreau ${ }^{2,4}$ (D) M. Vancoppenolle ${ }^{5}$ (D) F. Deman ${ }^{6}$ (D) A. Roukaerts ${ }^{6}$, \\ K. M. Meiners ${ }^{7,8}$ (DD, J. Janssens ${ }^{2,7}$, and D. Lannuzel ${ }^{2,7}$ \\ ${ }^{1}$ Scripps College, Claremont, CA, USA, ${ }^{2}$ Institute for Marine and Antarctic Studies, University of Tasmania, Hobart, \\ Tasmania, Australia, ${ }^{3}$ Now at Department of Earth System Science, Stanford University, Stanford, CA, USA, ${ }^{4}$ Norwegian \\ Polar Institute, Tromsø, Norway, ${ }^{5}$ Laboratoire d'Océanographie et du Climat (LOCEAN), Paris, France, ${ }^{6}$ Department of \\ Analytical, Environmental and Geo-Chemistry and Earth System Sciences, Vrije Universiteit Brussel, Brussels, Belgium, \\ ${ }^{7}$ Antarctic Climate and Ecosystems Cooperative Research Centre, University of Tasmania, Hobart, Tasmania, Australia, \\ ${ }^{8}$ Australian Antarctic Division, Department of the Environment and Energy, Kingston, Tasmania, Australia
}

Abstract We use field observations from late spring and a one-dimensional sea-ice model to explore a high nutrient, high chlorophyll system in Antarctic land-fast ice. Lack of variability in chlorophyll $a$ concentration and organic carbon content over the 17-day sampling period suggests a balance between macronutrient sources and biological uptake. Nitrate, nitrite, phosphate, and ammonium were measured at concentrations well above salinity-predicted levels, indicating nutrient accumulation fueled by remineralization processes. However, silicic acid (DSi) was depleted relative to seawater and was potentially limiting. One-dimensional physical-biogeochemical sea-ice model simulations at the observation site achieve extremely high algal growth and DSi uptake with a DSi half-saturation constant used for pelagic diatoms $\left(\mathrm{K}_{\mathrm{Si}}=3.9 \mu \mathrm{M}\right)$ and are not sufficiently improved by tuning the DSi:carbon ratio or DSi remineralization rate. In contrast, diatom biomass in the bottom ice, which makes up $70 \%$ of the observed chlorophyll, is simulated using $\mathrm{K}_{\mathrm{Si}}$ an order of magnitude higher $(50 \mu \mathrm{M})$, a value similar to that measured in a few Antarctic diatom cultures. Some sea-ice diatoms may therefore experience limitation at relatively high ambient DSi concentrations compared to pelagic diatoms. Our study highlights the urgent need for observational data on sea-ice algal affinity for DSi to further support this hypothesis. A lower algal growth rate increases model predictions of DSi in the upper sea ice to more accurate concentrations. The model currently does not account for the non-diatom communities that dominate those layers, and thus, modeling diatom communities overpredicts DSi uptake in the upper ice.

Plain Language Summary Microscopic, single-celled algae growing inside Antarctic sea ice play a small, but important, role in the carbon cycle of polar oceans. These algae use photosynthesis to convert carbon dioxide to organic carbon and are an important food source for larger organisms. The growth of sea-ice algae is partly controlled by their uptake of essential nutrients under favorable light conditions. Therefore, a better understanding of nutrients in sea ice can improve ecosystem models. We studied two weeks of measurements of coastal sea-ice characteristics in late spring at a site in East Antarctica. There were high amounts of both algae and nutrients, indicating recycling processes that return nutrients to the sea ice, even as algae consume nutrients. Sticky biofilms may also prevent nutrients from being removed by seawater. We then tested a sea-ice model to see if it matched our field measurements. We had to adjust how readily algal cells in the model take up silicon-a nutrient used to build diatoms' (the dominant algal group) walls - from their environment to obtain a close match. Previously used values were taken from experiments with non-ice associated marine algae, so better estimates specific to sea-ice algae are needed to accurately include sea-ice processes in large-scale models.

\section{Introduction}

Covering approximately $7 \%$ of the planet at its maximum (Weeks \& Hibler, 2010), sea ice is not only one of the world's largest biomes, supporting a variety of life, but also a fundamental feature of the Earth's climate system (Manabe \& Stouffer, 1980). Sea ice insulates the polar oceans from the atmosphere, limiting heat, mass, and momentum exchanges and reflecting a large part of solar radiation back to the atmosphere. 
The oceans have likely absorbed almost half of fossil-fuel emissions, with the Southern Ocean storing 9\% of that anthropogenic carbon (Sabine et al., 2004).

Sea ice provides a platform for many organisms, including primary producers, that live attached to the ice or in brine inclusions in the sea ice. With ice covering almost $17.9 \times 10^{6} \mathrm{~km}^{2}$ of the Southern Ocean at its maximum extent in 2018 (National Snow and Ice Data Center; Fetterer et al., 2017), sea-ice algae likely play a small but significant role in the Southern Ocean carbon cycle. Primary production in sea ice is estimated to contribute $\sim 12 \%$ of total production in the Antarctic sea-ice zone and $\sim 1 \%$ of total production in the Southern Ocean (Saenz \& Arrigo, 2014). In particular, regions with land-fast ice, which is held motionless through attachment to the coast, shallow shoals, or grounded icebergs, have a disproportionately large fraction of primary productivity relative to their surface areas (Arrigo et al., 1997, 2003; Meiners et al., 2018). This is most likely due to greater nutrient availability in comparison to offshore, free-drifting pack ice (van Leeuwe et al., 2018). Fast ice's proximity to more dynamic coastal and shelf currents (Cota et al., 1991) brings seawater with nutrient concentrations that are often higher than those of open ocean waters (Gradinger, 2009). There is also evidence that fast ice has iron levels at least an order of magnitude higher than most Antarctic surface waters (Lannuzel et al., 2016), providing an important micronutrient in the high nutrient, low chlorophyll Southern Ocean (Boyd et al., 2000; Boyd et al., 2012; Martin, 1990). Thus, in order to improve estimates of fast ice productivity, it is necessary to understand nutrient availability and uptake dynamics. Overall, knowing what drives and quantifying patterns of sea-ice productivity will clarify its role in rapidly changing polar climate systems.

Currently, calculations of primary productivity in Antarctic sea ice have large uncertainties, with estimates ranging from 23 to $70 \mathrm{Tg}$ C/year (Arrigo et al., 1997; Legendre et al., 1992; Saenz \& Arrigo, 2014). Numerical models of sea-ice biogeochemistry improve our ability to study an environment challenging for field sampling and remote satellite measurements. One-dimensional modeling studies of biogeochemical sea-ice processes published over the last two decades (e.g., Arrigo et al., 1991; Duarte et al., 2017; Lavoie et al., 2005; Tedesco et al., 2010; Vancoppenolle \& Tedesco, 2017) showed realistic simulations of the vertical structure and time variations of sea-ice chlorophyll, used as the main evaluation criterion when comparing observed and modeled quantities. However, Duarte et al. (2017) showed the difficulty of achieving realistic simulations of chlorophyll and nutrients in Arctic pack ice at the same time, partly due to limited knowledge of nutrient retention and motion within the brine matrix and at the ice-water interface. In addition, fundamental deficiencies in the predictive capability of such models remain. For instance, Lavoie et al. (2005) demonstrated that different parameters should be used for the same model to be successful at different sites. In this context, it is important to improve process understanding and observation-based model evaluations including all aspects of the system (algae, organic matter, nutrients, light, and brine dynamics). In particular, because macronutrient limitation often constrains primary productivity in Antarctic sea ice in the spring and summer, nutrient availability and supply processes are considered ideal subjects for joint field and model studies (Steiner et al., 2016).

The aim of this study is to characterize and quantify the biogeochemical processes that influenced primary production in Antarctic fast ice during a time series collected in spring. We combine sea-ice observations from East Antarctica and one-dimensional sea-ice modeling, focusing on both ice physics (e.g., temperature, salinity, and brine fraction) and biogeochemistry (e.g., chlorophyll $a$ [Chla], particulate organic carbon $[\mathrm{POC}]$, and macronutrient concentrations). We investigate the nutrient cycling processes that may underlie our measurements, and we examine possible limitations on sea-ice algal growth.

\section{Methods}

\subsection{Data Collection}

A time series of physical and biogeochemical data was collected from coastal land-fast sea ice and under-ice seawater at Davis Station, East Antarctica (68 $34^{\prime} 36^{\prime \prime} \mathrm{S}, 7^{\circ} 58^{\prime} 03^{\prime \prime} \mathrm{E}$; Figure 1) in late austral spring 2015 (Nov 16, Nov 20, Nov 23, Nov 26, Nov 29, and Dec 2). Sea-ice temperature, salinity, macronutrients (nitrate $\left[\mathrm{NO}_{3}{ }^{-}\right]$, nitrite $\left[\mathrm{NO}_{2}{ }^{-}\right]$, ammonium $\left[\mathrm{NH}_{4}{ }^{+}\right]$, phosphate $\left[\mathrm{PO}_{4}{ }^{3-}\right]$, and DSi), POC, and Chla were measured. Ice core depths were measured from the top of the ice cover. Ice cores were collected following trace-metal clean methods described in van der Merwe et al. (2009) using a 0.14-m internal diameter corer (Lichtert Industrie, Belgium) driven by an electric drill. At each sampling time, three ice cores (for temperature and salinity, for 


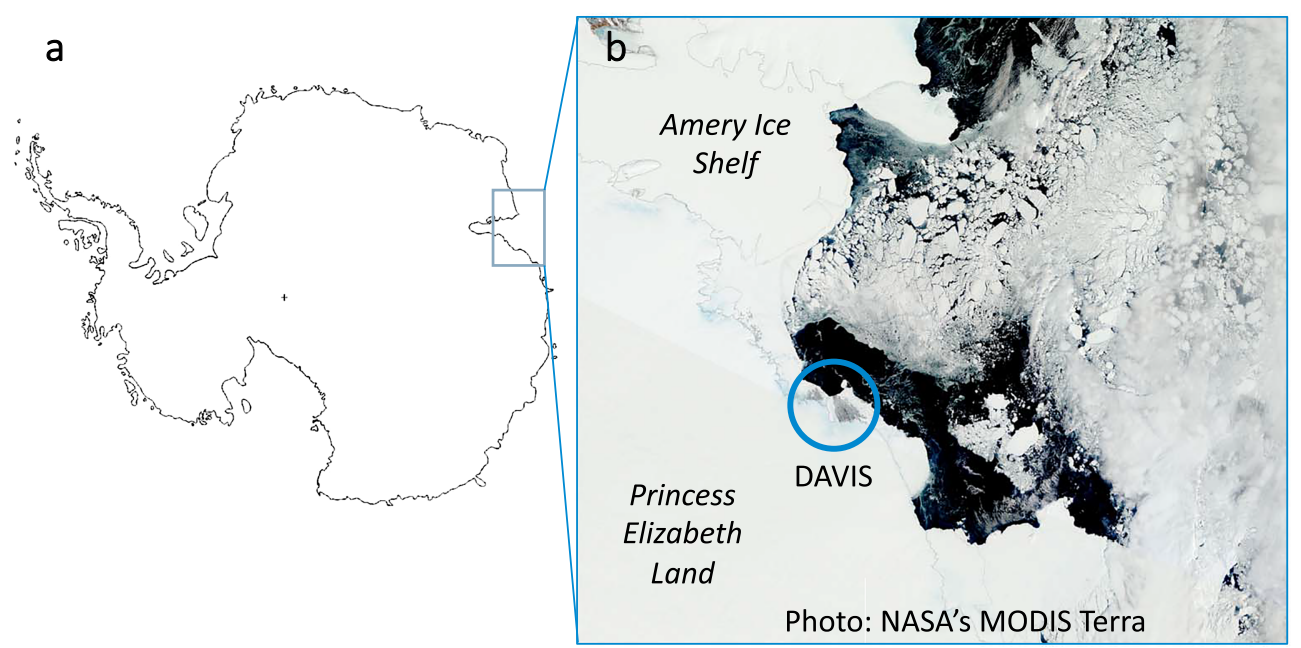

Figure 1. Location of Davis Station, Antarctica, outlined by blue circle on (a) general map of Antarctica and (b) image from NASA's Moderate Resolution Imaging Spectroradiometer (MODIS) Terra on 17 November 2015 (1 day after the start of the time series). Landmass of continent is outlined and on top is fast ice. The large glacier entering the sea is the Amery Ice Shelf.

Chla, and for POC and macronutrients) were collected about $0.1 \mathrm{~m}$ apart to minimize between-core variability. To minimize ice and brine loss during sampling, ice sections were cut directly after sampling (i.e., on the ice), starting from the bottom of the core, which is the most sensitive to light and brine loss. Under-ice seawater samples were collected following the methods from van der Merwe et al. (2011), with a custombuilt polycarbonate Helmond-Byrne water sampler suspended from a Kevlar line and triggered using an all-Teflon $^{\circledR}$ messenger (Sedwick et al., 1997). The sampler was lowered through the ice and triggered at 0-, 3-, and 10-m depths.

Ice core temperatures were measured from the first ice core approximately every $0.05 \mathrm{~m}$, starting $0.025 \mathrm{~m}$ from the top, by inserting a Testotherm 720 temperature probe (precision of $\pm 0.1{ }^{\circ} \mathrm{C}$ ) into a drilled hole. Salinity of 0.1-m melted ice core sections and seawater were measured using a Thermo Scientific Orion Model 125A Plus conductivity meter (precision of \pm 0.1 ). To increase the vertical resolution where biomass was the highest, the basal $0.1-\mathrm{m}$ ice core section was subsampled in two smaller sections of 0.06- and 0.04-m thickness.

Ice cores for biogeochemical parameters were cut in 0.1-m sections, again with 0.06 and $0.04 \mathrm{~m}$ subsampling in the lowest $0.1 \mathrm{~m}$, using a medical grade stainless steel bone saw (Richards Medical). The collected ice sections were placed in individual acid-cleaned melting containers and allowed to melt in the dark at room temperature (Rintala et al., 2014). Filters and all glassware in contact with the seawater and melted sea-ice samples dedicated to POC analysis were combusted at $450{ }^{\circ} \mathrm{C}$ for $12 \mathrm{hr}$ prior to sampling. Once fully melted, ice and seawater samples were gently stirred to homogenize before filtration $(0.2-2.5 \mathrm{~L})$ onto 25 -mmdiameter GF/F filters $(0.7 \mu \mathrm{m}$, Whatman) for POC and Chla determination. Two 20-ml samples were filtered over 25 -mm syringe filters $\left(0.2 \mu \mathrm{m}\right.$, Acrodisc), collected in $30-\mathrm{ml}$ plastic vials, and kept frozen at $-20{ }^{\circ} \mathrm{C}$ for macronutrient analysis. Filters for POC determination were directly dried overnight at $50{ }^{\circ} \mathrm{C}$ and stored in the dark at room temperature in pre-combusted vials. Filters for Chla were stored at $-80{ }^{\circ} \mathrm{C}$ until fluorometric analysis in the home laboratories.

Prior to analysis, inorganic carbon was removed from the POC filters by 24-hr exposure to concentrated hydrochloric acid fumes inside a closed glass container. Next, filters were packed in silver cups, and POC content was determined at the Vrije Universiteit Brussel (Belgium) using an elemental analyzer (EuroEA3000, Eurovector) coupled online via a Con-Flo III interface to a Thermo Delta V isotope ratio mass spectrometer (detection limit of $0.1 \mu \mathrm{g}$ and precision of 1\%). Chl $a$ was extracted in $90 \%$ acetone according to standard techniques (Holm-Hansen et al., 1965; Lorenzen, 1966). Samples were stored in the dark at $-20{ }^{\circ} \mathrm{C}$ for $24 \mathrm{hr}$ before analysis. A Turner Trilogy fluorometer, previously calibrated with Chla standards from Turner Designs (Sunnyvale, California), was then used to measure Chla (1.1\% precision). Dissolved 
inorganic nutrients $\left(\mathrm{NO}_{3}{ }^{-}+\mathrm{NO}_{2}{ }^{-}, \mathrm{NH}_{4}{ }^{+}, \mathrm{PO}_{4}{ }^{3-}\right.$, and DSi) concentrations were determined using an automated QuAAtro39 analyzer (Seal Analytical Inc.) following standard colorimetric methods (Hansen \& Koroleff, 1999). Nutrients were reacted and converted into a light-absorbing compounds whose absorbances were measured with a flow-through spectrophotometer. Concentrations were measured as bulk concentrations, representing the entire section of core (brine + ice). Precisions were $\pm 0.6 \mu \mathrm{M}$ for $\mathrm{NO}_{3}{ }^{-}+\mathrm{NO}_{2}{ }^{-}, \pm 0.1$

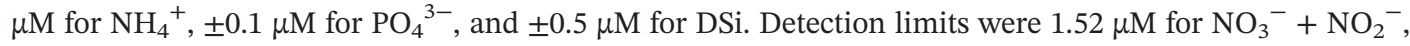
$0.37 \mu \mathrm{M}$ for $\mathrm{NH}_{4}{ }^{+}, 0.30 \mu \mathrm{M}$ for $\mathrm{PO}_{4}{ }^{3-}$, and $1.41 \mu \mathrm{M}$ for DSi.

\subsection{Analysis}

Brine fraction, or the amount of a given section of sea ice that exists as liquid brine within the ice, was calculated as a function of temperature and salinity (Cox \& Weeks, 1983). Because the depth intervals at which temperature and salinity were measured were not the same, temperatures matching the salinity measurement depths were interpolated using a parabolic best fit line $\left(R^{2}=0.99\right.$ Nov 16, 0.98 Nov 20, 0.99 Nov 23, 0.96 Nov 26, 0.96 Nov 29, and 0.89 Dec 30).

In abiotic ice systems, inorganic nutrients are generally considered to behave conservatively with salinity (Fripiat et al., 2017; Thomas et al., 2010). Theoretical dilution lines (TDLs), or the predicted concentration of nutrients for a given salinity, were established from nutrient concentrations in seawater $10 \mathrm{~m}$ below the ice, averaged for all six sampling days (standard deviations as a percent of the average: $2.8 \% \mathrm{NO}_{3}{ }^{-}+$ $\mathrm{NO}_{2}{ }^{-}, 77.7 \% \mathrm{NH}_{4}{ }^{+}, 2.5 \% \mathrm{PO}_{4}{ }^{3-}$, and $6.9 \% \mathrm{DSi}$ ). A depth of $10 \mathrm{~m}$ was chosen to minimize the influence of basal sea-ice algae communities and of fertilization as ice melts and releases nutrients at the icewater interface.

\subsection{Model}

LIM1D (version 3, source 3.26) is a one-dimensional model that includes a representation of the major physical and biogeochemical sea-ice characteristics (http://forge.ipsl.jussieu.fr/lim1d/wiki; Vancoppenolle et al., 2010; Vancoppenolle \& Tedesco, 2017). Sea ice is considered horizontally uniform with ten vertical layers of ice covered by a layer of snow; previous studies indicate that ten layers sufficiently resolve vertical profiles of biogeochemical processes (Moreau et al., 2014; Moreau et al., 2015; Vancoppenolle et al., 2010; Vancoppenolle \& Tedesco, 2017). For physical processes, the model includes (a) ice thermodynamics (growth and melt of sea ice and diffusion of heat), (b) brine transport (natural brine convection and percolation), and (c) radiative transfer, which assumes that $0.03 \mathrm{~m}$ of snow and $0.1 \mathrm{~m}$ of ice scatter the majority of radiation. Photosynthetic algae are assumed to be responsible for most nutrient cycling and carbon uptake; heterotrophic grazers are not included. A pool of detrital organic matter, which contributes to nutrient recycling, is also included in the model. Bacteria are not explicitly resolved by the model, but bacterial respiration and remineralization rates are calculated based on their relationship to sea-ice temperature (Moreau et al., 2015). Photosynthesis is limited by temperature, light, brine salinity, and macronutrients. The C:Chla ratio changes directly with photosynthetically active radiation (eq. 20.16 in Vancoppenolle \& Tedesco, 2017; Aumont et al., 2015; Doney et al., 1996). Macronutrients follow calculations of carbon content at a constant $\mathrm{C}: \mathrm{Si}: \mathrm{N}: \mathrm{P}=106: 12: 16: 1$ molar ratio, according to the Redfield ratio with the addition of silicon for diatom uptake (Brzezinski, 1985; Redfield et al., 1963; Sarthou et al., 2005). Photosynthetic limitation by a specific factor is calculated and ranked on a scale from 0, maximum limitation, to 1 , minimum limitation (Vancoppenolle \& Tedesco, 2017). The model has a temporal resolution of $1 \mathrm{hr}$, for a total of 385 time steps over the 17-day period. For further details about LIM1D, please see Vancoppenolle et al. (2010) and Vancoppenolle and Tedesco (2017).

The model was initialized using observed thermodynamic and biogeochemical profiles from the first day of observations. We used atmospheric temperature, specific humidity, wind speed, and atmospheric pressure recorded over the whole sampling period (mid-November to early December) at Davis to force the model. Atmospheric data were retrieved from the Antarctic Climate Data Collected by Australian Agencies database (Barnes-Keoghan, 2000). Data for daily precipitation were not available, so a fixed rate of $0.01 \mathrm{~m} /$ day was used to match the observed snow cover.

The model was first run with default values for biological parameters (based on laboratory and field-based values from the literature; Table 1) to evaluate how closely the model outputs matched the biogeochemical observations. 
Table 1

Model Parameters

\begin{tabular}{|c|c|c|c|}
\hline Parameter & Units & Control value & Sensitivity runs \\
\hline Maximum specific growth rate ${ }^{a}$ & $\mathrm{~s}^{-1}$ & $3.0 \times 10^{-5}$ & $3.0 \times 10^{-6}, 3.0 \times 10^{-4}$ \\
\hline Algal decay rate ${ }^{a}$ & $\mathrm{~s}^{-1}$ & $1.0 \times 10^{-6}$ & \\
\hline Remineralization rate ${ }^{\mathrm{b}}$ & $\mathrm{s}^{-1}$ & $2.0 \times 10^{-7}$ & $2.0 \times 10^{-8}, 2.0 \times 10^{-6}$ \\
\hline Si:C ratio ${ }^{c}$ & - & 0.11 & $0.04,0.95$ \\
\hline $\mathrm{N}: \mathrm{C}$ ratio ${ }^{\mathrm{c}}$ & - & 0.14 & \\
\hline $\mathrm{P}: \mathrm{C}$ ratio ${ }^{\mathrm{c}}$ & - & 0.0094 & \\
\hline Half-saturation constant for $\mathrm{N}^{\mathrm{c}}$ & $\mu \mathrm{M}$ & 1.6 & \\
\hline Half-saturation constant for $\mathrm{P}^{\mathrm{c}}$ & $\mu \mathrm{M}$ & 0.24 & \\
\hline Half-saturation constant for $\mathrm{Si}^{\mathrm{c}}$ & $\mu \mathrm{M}$ & 3.9 & 50,100 \\
\hline
\end{tabular}

${ }^{\mathrm{a} C a l i b r a t e d}$ (Vancoppenolle \& Tedesco, 2017). ${ }^{\mathrm{b}}$ Based on remineralization rate of carbon in sea ice (Moreau, Vancoppenolle, et al., 2015). $\quad$ c Based on observed pelagic diatom physiology (Redfield et al., 1963; Sarthou et al., 2005; Sommer, 1986).

Several sensitivity assessments were then run to examine possible limitations on algal growth in the fast ice at Davis. In particular, parameters controlling DSi supply and uptake were changed according to ranges of values found in past laboratory and modeling assessments (Table 1). The rationale behind these sensitivity analyses is described in section 3.4, but we list here the technical details. The DSi:C incorporation ratio, set in the control run at 0.11 , was also tested at 0.04 and 0.95 to simulate different extents of algal DSi uptake. For pelagic diatoms, Brzezinski's (1985) laboratory experiments found DSi:C $=0.12$ and 0.13, while Sarthou et al.'s (2005) review found DSi:C $=0.11$. Remineralization rates an order of magnitude above and below $2 \times 10^{-7} \mathrm{~s}^{-1}$ (Moreau, Kaartokallio, et al., 2015) were then tested to estimate the effect of diatom frustule dissolution. By testing $3.0 \times 10^{-4} \mathrm{~s}^{-1}, 3.0 \times 10^{-5} \mathrm{~s}^{-1}$ (control), and $3.0 \times 10^{-6} \mathrm{~s}^{-1}$ for the maximum specific growth rate $\left(\mu_{\max }\right)$, which controls biogenic silica $\left(\mathrm{bSiO}_{2}\right)$ production, dissolution to production ratios were varied as $0.0007,0.007$, and 0.07 , respectively. Though lower than Fripiat et al. (2014)'s $\mathrm{bSiO}_{2}$ dissolution to production ratio ranging from 0.4 to 0.9 , these were taken from a LIM1D calibration (Vancoppenolle \& Tedesco, 2017). Finally, since no laboratory-based data on DSi half-saturation constants $\left(\mathrm{K}_{\mathrm{Si}}\right)$ in sea ice currently exist, different $\mathrm{K}_{\mathrm{Si}}$ values were based on a range measured for pelagic diatoms: $\mathrm{K}_{\mathrm{Si}}=3.9 \mu \mathrm{M}$ (Sarthou et al., 2005; Vancoppenolle \& Tedesco, 2017) as used in past LIM1D model simulations, $\mathrm{K}_{\mathrm{Si}}=100 \mu \mathrm{M}$ as an upper limit of the 88.7- $\mu \mathrm{M}$ maximum value measured for cultures of Southern Ocean diatoms (Sommer, 1986), and $\mathrm{K}_{\mathrm{Si}}=50 \mu \mathrm{M}$ as a midrange value.

\section{Results}

\subsection{Sea-Ice Physics}

The site at Davis had a medium snow cover that increased from 0.18 to $0.36 \mathrm{~m}$ during the 17 -day time series. Sea ice was on average $1.66 \pm 0.04 \mathrm{~m}$ (mean \pm standard deviation, $n=6)$ thick. With the maximum ice observed on Nov 20 and Nov 29 (Stations 2 and 5, respectively), spatial heterogeneity may be partly responsible for the variability in ice thicknesses. Temperature in the fast ice generally increased with depth and over time (Figure 2a). The amplitude of change over time was greatest at the top of the ice, where temperature increased from $-5.3{ }^{\circ} \mathrm{C}$ on the first day to $-2.9{ }^{\circ} \mathrm{C}$ on the last. Temperature at the base of the ice remained consistently between $-1.7^{\circ} \mathrm{C}$ and $-2.0^{\circ} \mathrm{C}$, close to seawater freezing temperature.

The sea ice had a "C-shaped" salinity profile, with bulk salinity averaging $5.3 \pm 0.9(n=35)$ in the top of the ice $(0-0.6 \mathrm{~m}), 4.1 \pm 0.4(n=44)$ in the middle of the ice $(0.6-1.3 \mathrm{~m})$, and $6.6 \pm 2.7(n=22)$ in the lower ice (1.30-1.65 m; Figure $2 \mathrm{~b}$ ). There was no strong temporal trend in sea-ice salinity. Brine volumes were largest at the base of the ice (five to eight times greater than at the middle or top; Figure 2c) where the ice is warmest and most saline. Sea ice with a columnar structure and a brine volume fraction over $5 \%$ is considered permeable, as previously isolated brine pockets connect via brine channels (Golden et al., 1998). The observed sea ice was permeable except some portions of the top $0.8 \mathrm{~m}$ in the earlier sampling days (mostly Nov 20 and 23, one point on Nov 26). Thus, brine and seawater could move and be exchanged throughout the fast ice for all days at the base and, during the second half of the time series, also at the top. 


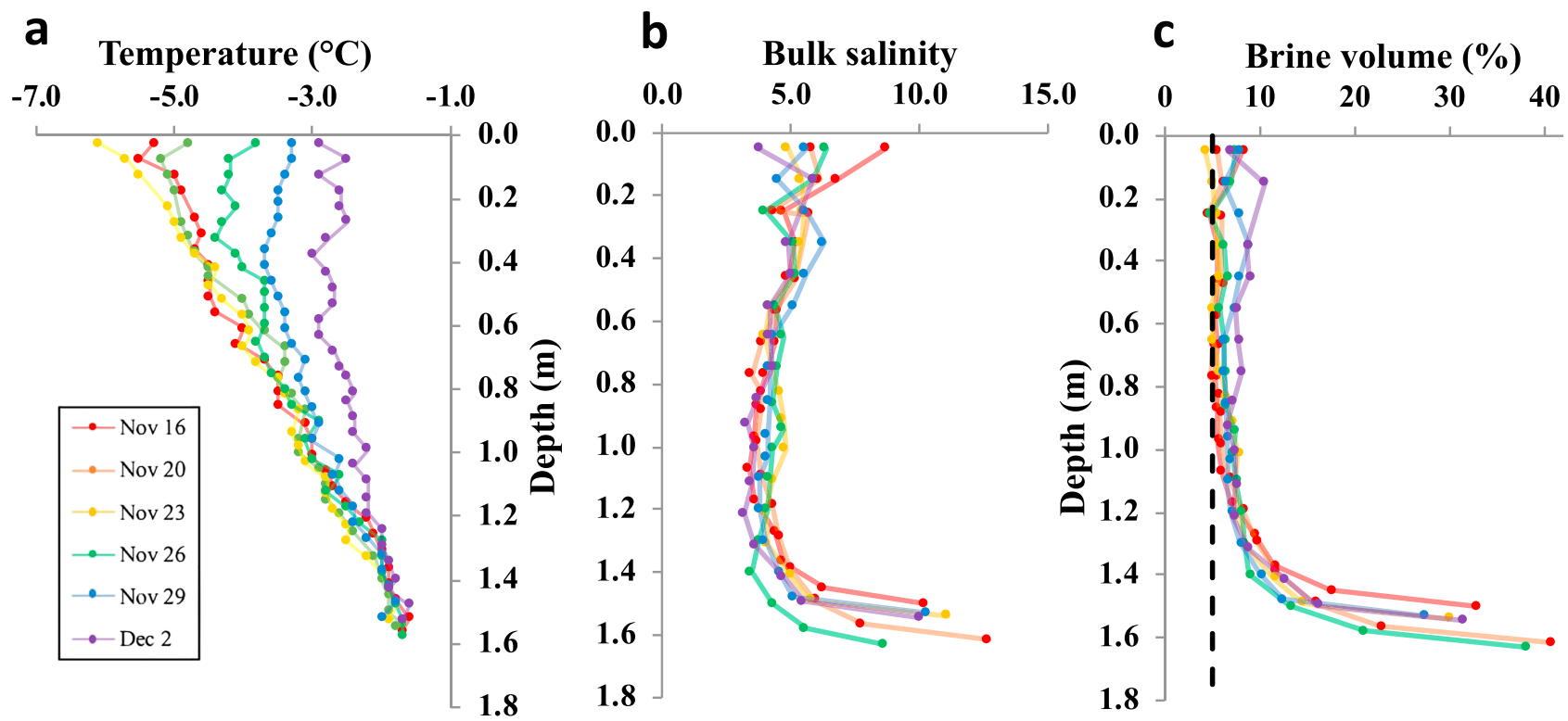

Figure 2. (a) Temperature, (b) bulk salinity, and (c) brine volume fraction vertical profiles for each sampling day. Dashed vertical line marks the 5\% permeability threshold.

\subsection{Sea-Ice Biogeochemistry}

Chla was used as a proxy for biological activity by photosynthetic sea-ice algae. Although there was a small amount of Chla at depths of 0-1.3 m, over 70\% of the total integrated Chla biomass was at the bottom of the ice, with concentrations between 163.5 and $267.4 \mu \mathrm{g} / \mathrm{L}$ (Figure 3a). Microscopy qualitatively identified the pennate diatoms in the bottom ice as Nitzschia stellata, Nitzschia lecointei, Fragilariopsis cylindrus, Entomoneis kjellmanii, and Pleurosigma sp., as well as some unidentified, chain-forming, centric diatoms
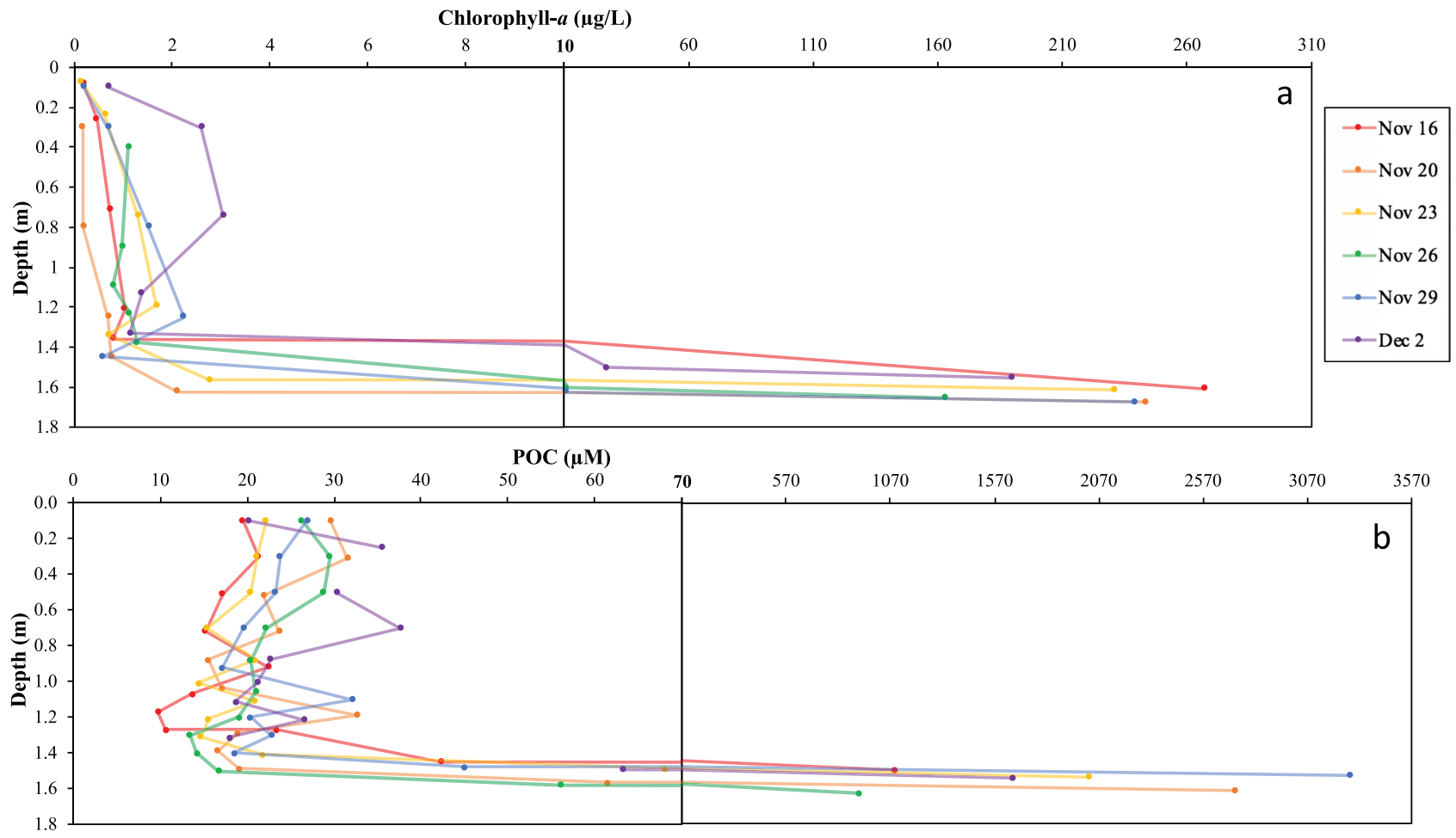

Figure 3. (a) Chla and (b) POC concentration vertical profiles for each sampling day. 

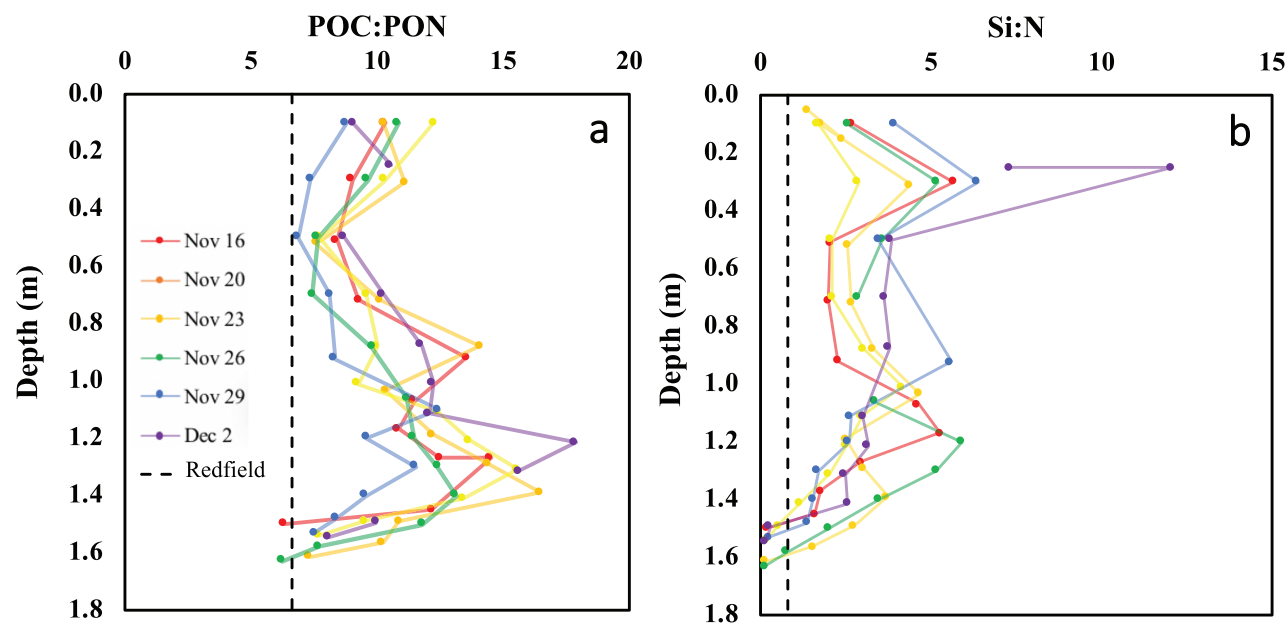

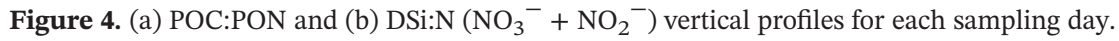

(Supporting Information, Figure S1, identified by Phillip Assmy; additional observations by Andreas Seger and Fraser Kennedy). There were no algal strands attached to the base of the ice. Chla concentrations in the seawater were up to three orders of magnitude smaller, averaging $0.17 \pm 0.11 \mu \mathrm{g} / \mathrm{L}(n=6)$ right below the ice and $0.12 \pm 0.07 \mu \mathrm{g} / \mathrm{L}(n=6) 10 \mathrm{~m}$ below. There was no clear temporal trend in the bottom sea-ice Chla concentrations. Evidence suggest a small increase in intermediate and upper ice Chla over time, from levels at or below $1.03 \mu \mathrm{g} / \mathrm{L}$ on the first day to levels up to $3.04 \mu \mathrm{g} / \mathrm{L}$ on the last day (Figure 3a). POC ranged between $9.7 \mu \mathrm{M}$ in internal sea ice and 3,270 $\mu \mathrm{M}$ at the bottom of the ice (Figure 3b). Seawater POC was up to three orders of magnitude smaller, ranging from 2.6 to $20.5 \mu \mathrm{M}$. There was no temporal trend in POC in the intermediate and upper ice nor the bottom ice (Figure $3 \mathrm{~b}$ ). The intermediate and upper ice had slightly higher POC:PON ratios $(10.9 \pm 2.4, n=60)$ than basal ice $(7.1 \pm 0.8, n=6$; Figure $4 \mathrm{a})$, which exhibited near-Redfield ratios (6.6, Redfield et al., 1963).

On every sampling day, macronutrients were much more concentrated in the bottom ice $\left(\mathrm{NO}_{3}{ }^{-}+\mathrm{NO}_{2}{ }^{-}=\right.$ $\left.69.26 \pm 40.69, \mathrm{NH}_{4}{ }^{+}=3.05 \pm 1.17, \mathrm{PO}_{4}{ }^{3-}=7.41 \pm 2.14, \mathrm{DSi}=13.68 \pm 11.6 \mu \mathrm{M}, n=6\right)$ than in other ice layers $\left(\mathrm{NO}_{3}{ }^{-}+\mathrm{NO}_{2}{ }^{-}=1.38 \pm 0.86, \mathrm{NH}_{4}{ }^{+}=0.76 \pm 0.75, \mathrm{PO}_{4}{ }^{3-}=0.23 \pm 0.19, \mathrm{DSi}=4.11 \pm 1.58 \mu \mathrm{M}, n=47\right)$. For all macronutrients except DSi, the bottom ice was also enriched compared to seawater 0,3 , and $10 \mathrm{~m}$ under the ice $\left(\mathrm{NO}_{3}{ }^{-}+\mathrm{NO}_{2}{ }^{-}=29.28 \pm 0.69, \mathrm{NH}_{4}{ }^{+}=0.29 \pm 0.23, \mathrm{PO}_{4}{ }^{3-}=2.10 \pm 0.22, \mathrm{DSi}=52.40 \pm 2.74 \mu \mathrm{M}, n=18\right)$. Concentrations in the seawater, intermediate ice, and upper ice sometimes fell below the detection limits of the analytical instrument. Although there was some variability in measurements over the 17 days, overall, there was no discernable trend in macronutrient concentrations.

Bulk inorganic macronutrient concentrations are plotted as a function of bulk ice salinity (Figure 5). Nitrate and $\mathrm{NO}_{2}{ }^{-}$concentrations fell below the TDL, except for the bottom layer in which they were consistently well above the TDL (Figure 5a). Ammonium was often well above the TDL (Figure 5b), with sea-ice concentrations sometimes an order of magnitude larger than that of the seawater. In a pattern similar to $\mathrm{NO}_{3}{ }^{-}+$ $\mathrm{NO}_{2}{ }^{-}, \mathrm{PO}_{4}{ }^{3-}$ followed or was slightly below the TDL, except for all the bottom sections and a few other depths from Nov 20 (Figure 5c). Other than one point (bottom layer on Nov 29), DSi was always below the TDL (Figure 5d). At times, the difference between DSi and the TDL was over $5 \mu \mathrm{M}$, a fairly large amount given typical bulk sea-ice DSi concentrations of 0-10 $\mu \mathrm{M}$ (Fripiat et al., 2017). Compared to Brzezinski (1985) DSi:N ratio of $0.95-1.12$ for marine diatoms, there was relatively more DSi than $\mathrm{N}$ in the intermediate and upper ice $(3.2 \pm 1.8, n=60)$ and less in the basal ice $(0.2 \pm 0.04, n=6$; Figure $4 \mathrm{~b})$.

\subsection{Control Simulation Output}

In the control simulation using previously calibrated, literature-based parameters (Table 1), the model agreed closely with the ice thickness and snow depths (blue plus signs, Figure 6a). There was $0.022 \mathrm{~m}$ of modeled ice loss over 17 days. Given the spatial heterogeneity between cores, this is a decent estimation of the observed ice loss of $\sim 0.04 \mathrm{~m}$. The model calculated brine volume fraction, with permeability above 

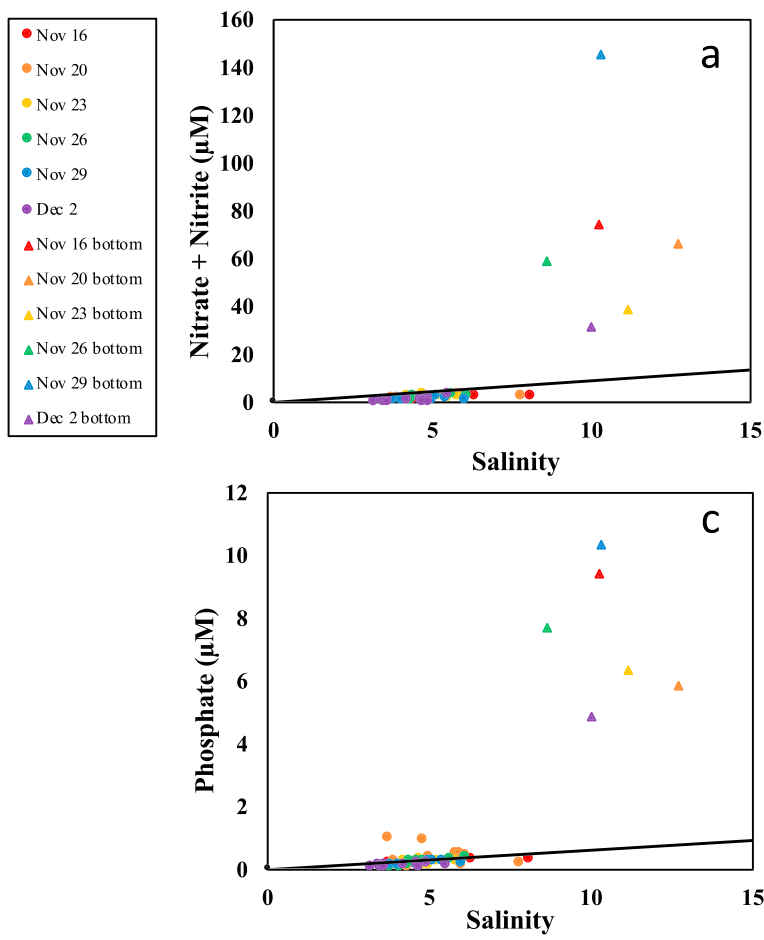
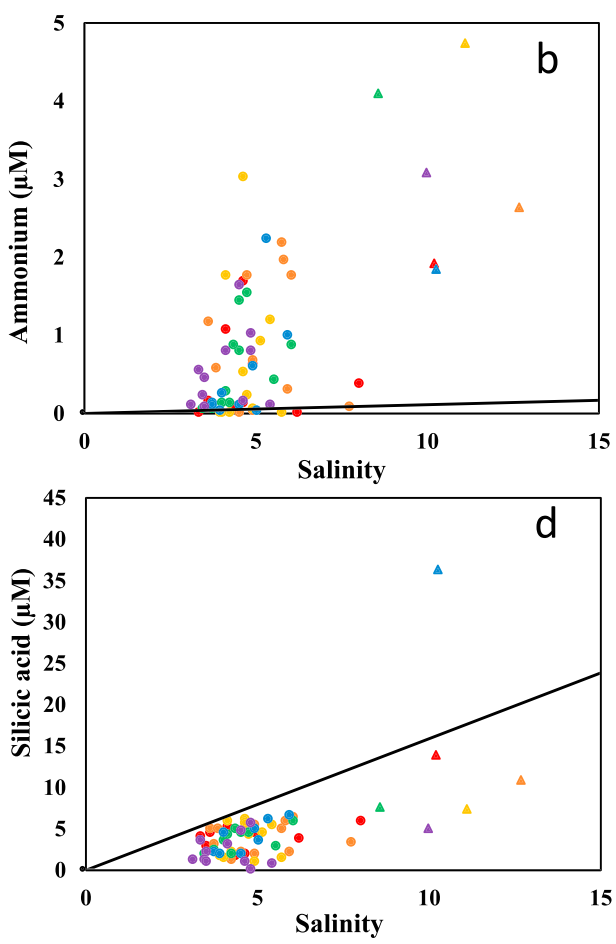

Figure 5. Macronutrient bulk concentrations (a) $\mathrm{NO}_{3}{ }^{-}+\mathrm{NO}_{2}{ }^{-}$, (b) $\mathrm{NH}_{4}{ }^{+}$, (c) $\mathrm{PO}_{4}{ }^{3-}$, and (d) DSi as a function of salinity for each sampling day. Theoretical dilution lines (solid black lines) were established from nutrient concentrations in seawater $10 \mathrm{~m}$ below the ice, averaged for all six time points.

the 5\% theoretical threshold throughout the whole time series (Figure 7c). Light limited primary production on a daily cycle (Figure 6b), and brine salinity was limiting in the upper ice cover throughout the whole time series (not shown). Chla was enriched in the bottom sea ice, with values above $100 \mu \mathrm{g} / \mathrm{L}$, and showed some regulation by the light-dark cycle (Figure 6c). Nitrate, $\mathrm{NO}_{2}{ }^{-}$, and $\mathrm{PO}_{4}{ }^{3-}$ never reached limiting concentrations (Figures $6 \mathrm{~d}$ and $6 \mathrm{e}$ ). Silicic acid was limiting (Figure 6f), with a decrease in concentration in the internal ice but some increase in the bottom ice over time (Figure $6 \mathrm{~g}$ ).

Because there was generally little temporal evolution in macronutrient concentrations, depth profiles, both for observations and the model outputs, are depicted as an average over the entire sampling period (Figure 7). Initialized with values from the first day of observations, the model simulated the sea-ice temperature (Figure 7a), salinity (Figure 7b), and brine volume (Figure 7c) at different depths relatively well, except for an underestimation of salinity in the bottom ice (Figure 7b). Chla was greatly overestimated in the bottom ice (Figure 7d). For biogeochemical parameters, the control simulation showed a slight overestimation of POC at 0.7-0.9 relative depth, but otherwise mostly matched observed profiles (Figure 7e). It reproduced $\mathrm{NO}_{3}{ }^{-}+\mathrm{NO}_{2}{ }^{-}$(Figure $7 \mathrm{f}$ ) and $\mathrm{PO}_{4}{ }^{3-}$ (Figure $7 \mathrm{~g}$ ) well. However, the model largely underestimated DSi, with a depth-integrated value of $2.61 \pm 1.89 \mathrm{mmol} / \mathrm{m}^{2}(n=385)$ compared to the observed $5.88 \pm 1.24 \mathrm{mmol} / \mathrm{m}^{2}$ ( $n=6$; Figure $7 \mathrm{~h}$ ). Both in the observations and control simulation, DSi in the bottom ice was depleted relative to seawater (Figure $7 \mathrm{~h}$ ).

\subsection{Sensitivity Analysis of the Model to DSi Limitation}

Given the control simulation's DSi limitation and difficulty matching Chla and DSi observations, these characteristics were chosen as foci for model tuning and to elucidate the biogeochemical processes in the fast ice system. In all sensitivity runs, the model's simulations of physical characteristics, $\mathrm{NO}_{3}{ }^{-}+\mathrm{NO}_{2}{ }^{-}$, and $\mathrm{PO}_{4}{ }^{3}$ were not affected. Compared to the control run, decreasing the DSi:C ratio to 0.04 overestimated Chla (red line, Figure 8a) but caused a more accurate fit to DSi observations in the upper part of the ice (red line, Figure $8 \mathrm{~b}$ ). Increasing DSi:C to 0.95 led to a relatively accurate Chla simulation in the upper ice (blue line, Figure 8a) but a slight overestimation of DSi concentrations in the bottom ice (blue line, Figure 8b). The 

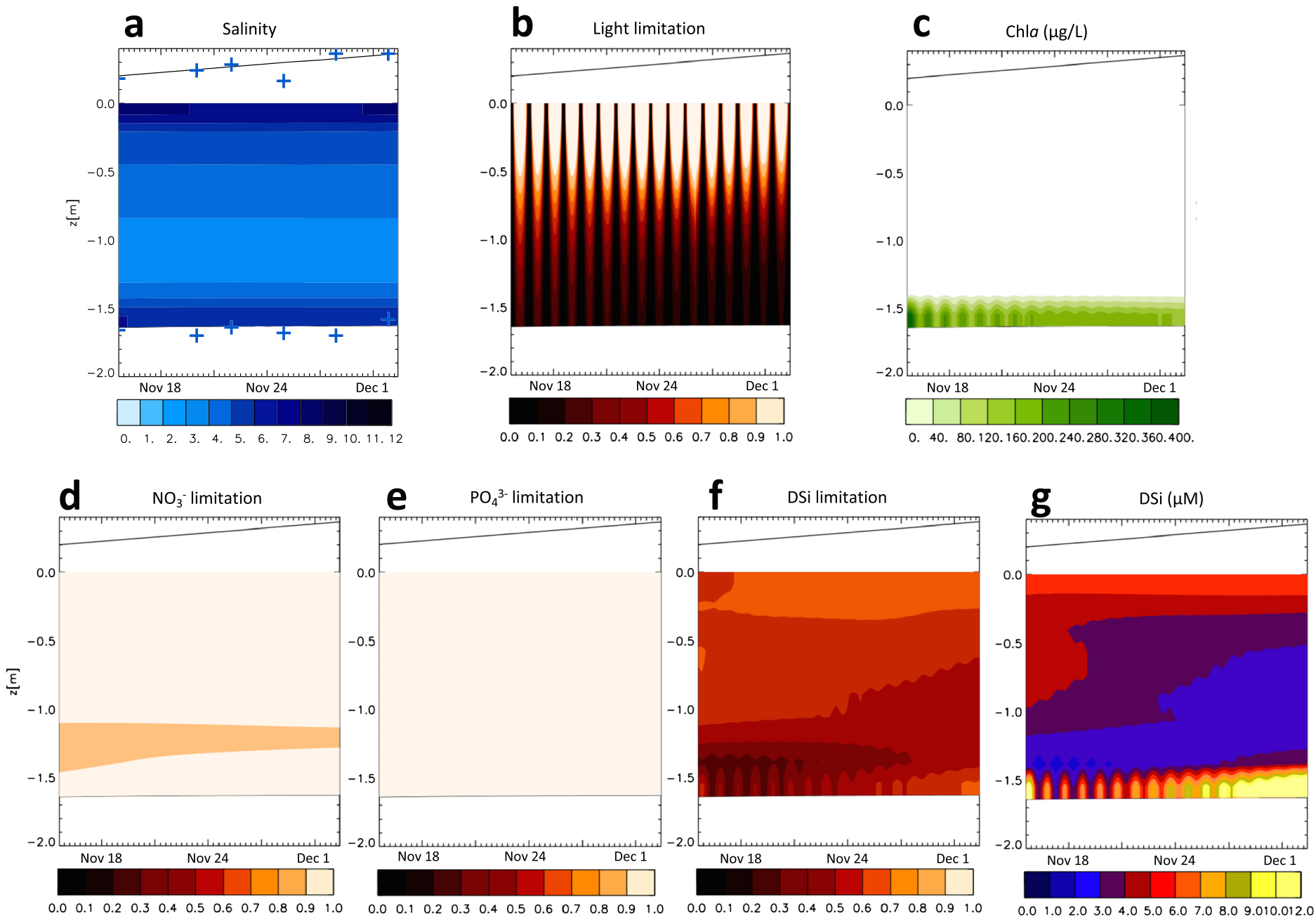

Figure 6. Contoured (a) salinity, (b) light limitation, (c) Chla bulk concentration, (d) $\mathrm{NO}_{3}{ }^{-} / \mathrm{NO}_{2}{ }^{-}$limitation, (e) $\mathrm{PO}_{4}{ }^{3-}$ limitation, (f) DSi limitation, and (g) DSi bulk concentration for a control run. Limitations are without units on a scale from 0 (maximum limitation) to 1 (no limitation). Vertical axes are depth. Observations of snow depth and ice thickness are also plotted (plus signs) on (a). Black line on top of each panel represents modeled snow thickness.

intermediate DSi:C value of 0.11 produced the closest fit to both Chla and DSi observations (green line, Figure 8), although all three runs overestimated Chla in the bottom of the sea ice.

Decreasing the remineralization rate 10 times from the control run $\left(2 \times 10^{-8} \mathrm{~s}^{-1}\right)$ led to a slight underestimation of DSi observations in the basal ice (red line, Figure 9b), while increasing the remineralization rate (2 $\times 10^{-6} \mathrm{~s}^{-1}$ ) led to a large overestimation of DSi and Chla concentrations at the bottom of the ice (blue line, Figure 9). In the upper ice, decreasing $\mu_{\max }$ by an order of magnitude $\left(3 \times 10^{-6} \mathrm{~s}^{-1}\right)$ better matched DSi observations (red line, Figure 10b) compared to the control run, but otherwise changing $\mu_{\max }$ did not particularly improve model output of Chla and DSi (Figure 10).

When the lowest $\mathrm{K}_{\mathrm{Si}}$ value was used, the model output overestimated Chla and underestimated DSi (green line, Figure 11). When the highest $\mathrm{K}_{\mathrm{Si}}$ value was used, DSi output was too high in the lower ice, while Chla matched DSi observations fairly well (blue line, Figure 11). An intermediate $\mathrm{K}_{\mathrm{Si}}$ value of $50 \mu \mathrm{M}$ produced the closest combined fit to both Chla and DSi observations (red line, Figure 11).

\section{Discussion}

\subsection{Status of the Biogeochemical Reservoirs}

Sea ice at Davis displayed physical characteristics that are typical of Antarctic fast ice during spring, such as warming temperatures at the surface of the ice and a "C"-shaped salinity profile (Petrich \& Eicken, 2010). 

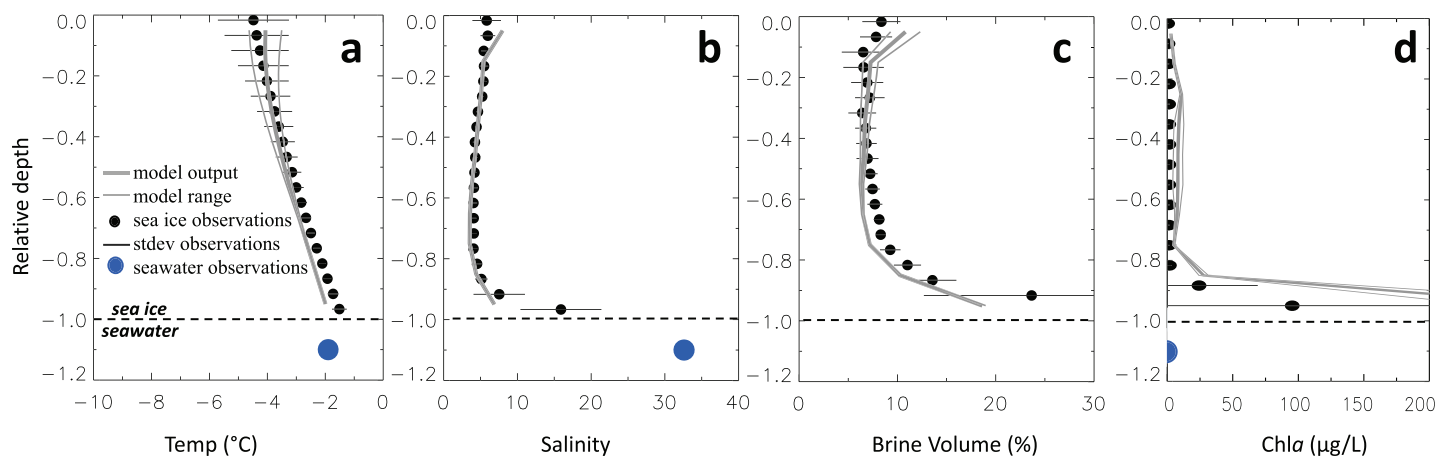

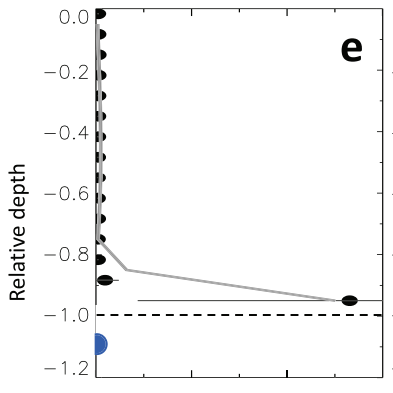

$\mathrm{POC}(\mu \mathrm{M})$
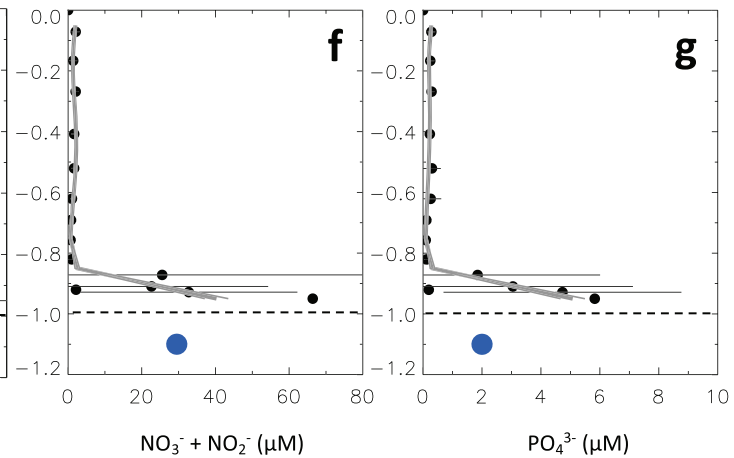

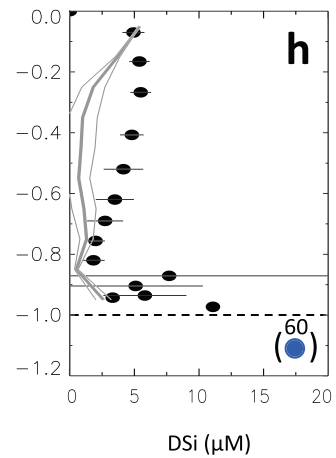

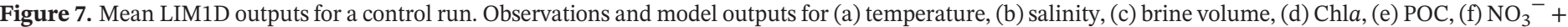
$\mathrm{NO}_{2}{ }^{-},(\mathrm{g}) \mathrm{PO}_{4}{ }^{3-}$, and (h) DSi. All concentrations are bulk ice concentrations. Vertical axes are normalized relative depths, with a maximum depth of one.

The model closely matched the observed ice physics, although it should be noted that the time series is relatively short and has little evolution. Because the model was initialized with the first day of observations, this likely contributes to the agreement between the observed and modeled quantities over the 17-day simulation period.

Since there are little to no temporal trends in the Chla, POC, and macronutrients measurements throughout the time series, our sampling appears to mark a period without major biomass accumulation or decline. Previous work in the area suggests that sea-ice algal biomass near Davis generally peaks in October (Swadling et al., 2004). Compared to other Antarctic fast ice studies in November-December, basal Chla concentrations in this study $(163.5-267.4 \mu \mathrm{g} / \mathrm{L})$ are one order of magnitude higher than maximum concentrations observed at Terra Nova Bay $(34.2 \mu \mathrm{g} / \mathrm{L}$, Grotti et al., 2005) and at Davis in 1993 (69 $\mu \mathrm{g} / \mathrm{L}$, Archer et al., 1996), but similar to those at Casey Station (235 $\mu \mathrm{g} / \mathrm{L}$, van der Merwe et al., 2011). As this study falls
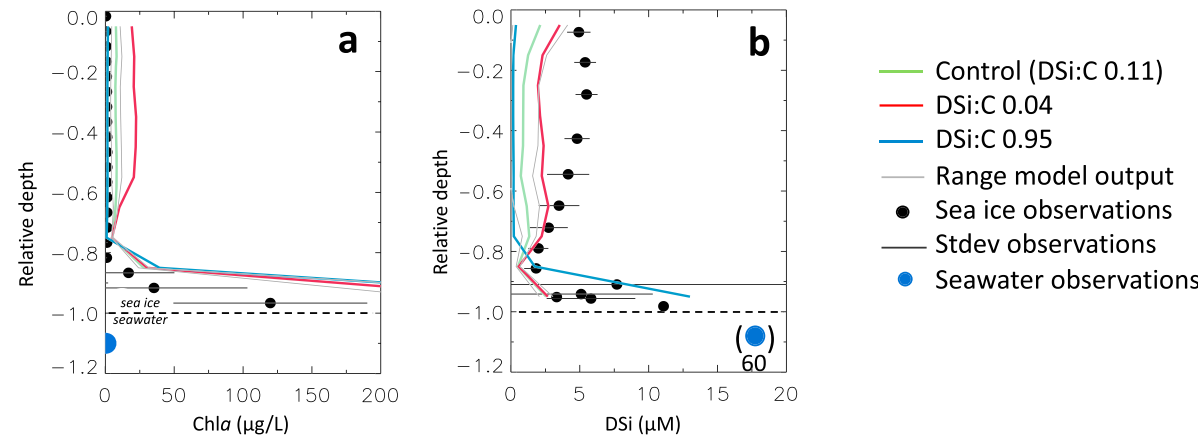

Figure 8. LIM1D sensitivity tests for different DSi:C ratios, comparing mean observations to mean model outputs for (a) Chla and (b) DSi concentrations. Vertical axes are relative depths, with a maximum depth of one. 

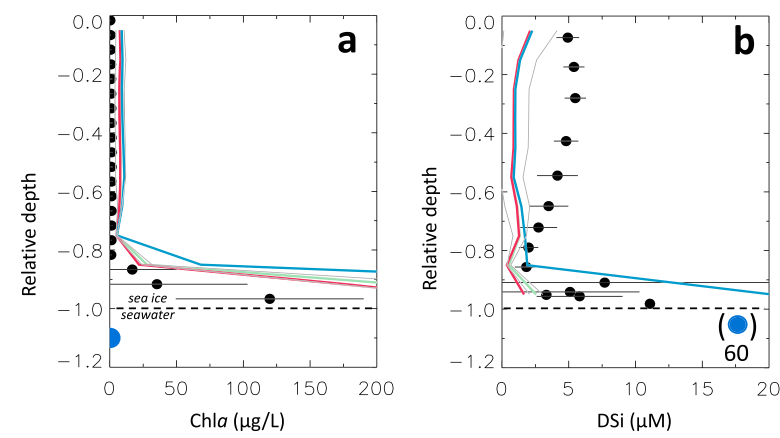

- Control (remin $\left.2 \times 10^{-7} \mathrm{~s}^{-1}\right)$

- Remin $2 \times 10^{-8} \mathrm{~s}^{-1}$

- Remin $2 \times 10^{-6} \mathrm{~s}^{-1}$

- Range model output

- Sea ice observations

- Stdev observations

- Seawater observations

Figure 9. LIM1D sensitivity tests for different remineralization rates, comparing mean observations to mean model outputs for (a) Chla and (b) DSi concentrations. Vertical axes are relative depths, with a maximum depth of one.

on the high end of observed values in Antarctic fast ice (excluding sites with platelet ice, e.g., Meiners et al., 2018), the algal population may be unlikely to accumulate further.

Two factors that challenge our ability to observe changes in the algal population, particularly in the bottom ice, are gradual ice melt as the spring warms into summer, and the possible loss of material via brine drainage from the bottom of the cores during sampling. Either of these could lead to an underestimation of Chla. Over the 17-day period, we estimate that ice thickness loss due to melting was $0.02-0.04 \mathrm{~m}$ (Figure 6a). Given the dense accumulation of algae in the bottom ice, it is possible that this contributes to the apparent stability of Chla, and slight ice loss should be retained as a limitation of this study. This is perhaps reflected in a minor decrease in Chla concentrations in the model simulation (Figure 6c). With regard to sampling, along with the precautions taken to retain as much of the cores as possible, negative air temperatures $\left(-2.9 \pm 1.5^{\circ} \mathrm{C}\right)$ kept cores below their melting point. In situ sea-ice temperatures were relatively cold (Figure 2a), helping to keep the biomass attached to the ice matrix. What is lost is generally associated with the dissolved phase, while particulate matter (and therefore Chla) tends to remain attached to the walls of the brine channels (Becquevort et al., 2009; Lannuzel et al., 2016). Overall, within these considerations, we maintain the integrity of the observations as generally representative of the fast ice system and dynamics.

Our observations of co-occurring high macronutrients $\left(\mathrm{NO}_{3}{ }^{-}+\mathrm{NO}_{2}{ }^{-}, \mathrm{NH}_{4}{ }^{+}, \mathrm{PO}_{4}{ }^{3-}\right.$, not DSi; Figure 5) and chlorophyll reveal a relatively stable system. High nutrient concentrations are able to support a large sea-ice algae community, while other processes simultaneously replace these nutrients. Note that the nutrient measurements were for melted ice sections (i.e., bulk concentration), which include liquid brine and solid ice. As macronutrients are in reality dissolved within brine inclusions, the nutrient concentrations that algae experience in situ (i.e., brine-normalized) are therefore higher than the reported bulk concentrations. Unless sea-ice algae rely primarily on intracellular nutrient pools, there must exist processes that replenish these concentrated sea-ice nutrient pools. Physical supply processes, such as natural brine convection due to a cooler ice surface (Reeburgh, 1984) or forced brine convection by tides (Cota et al., 1987; Cota \& Horne,
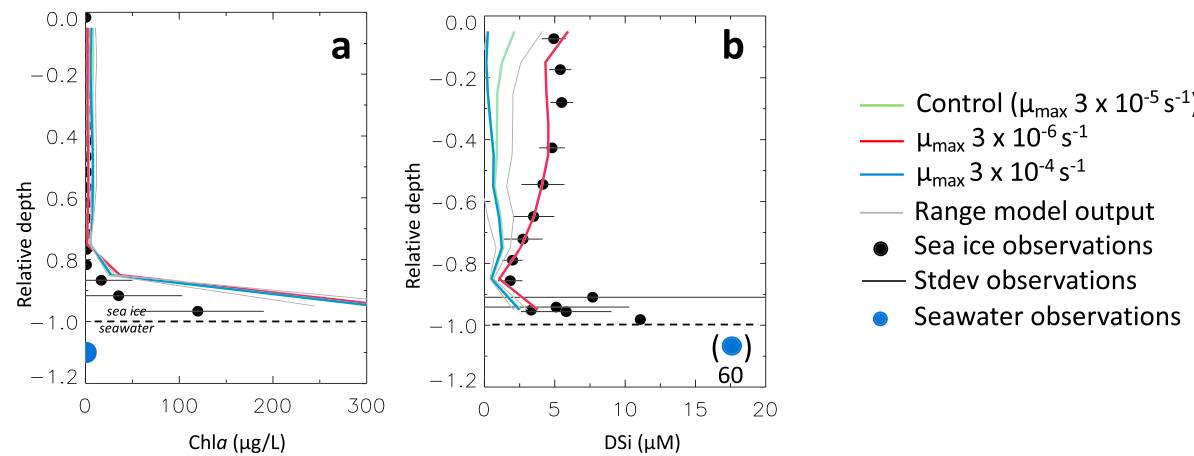

Figure 10. LIM1D sensitivity tests for different maximum growth rates, comparing mean observations to mean model outputs for (a) Chla and (b) DSi concentrations. Vertical axes are relative depths, with a maximum depth of one. 

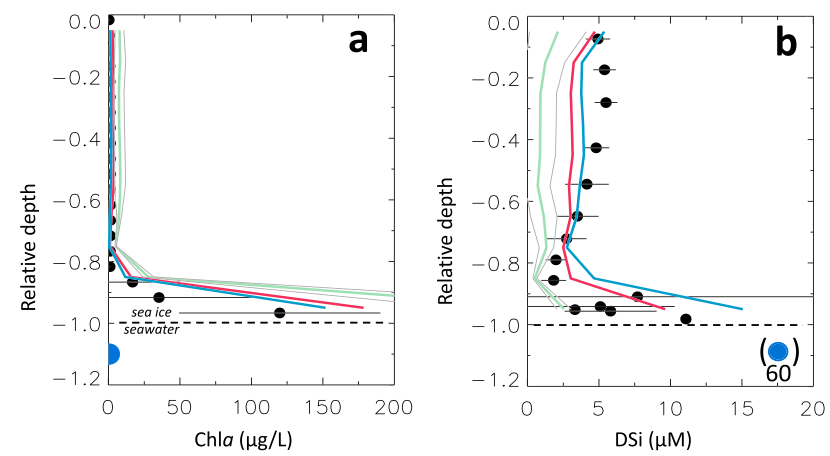

- Control $\left(\mathrm{K}_{\mathrm{Si}} 3.9\right)$

$-\mathrm{K}_{\mathrm{Si}} 50$

$-\mathrm{K}_{\mathrm{Si}} 100$

- Range model output

- Sea ice observations

- Stdev observations

- Seawater observations

Figure 11. LIM1D sensitivity tests for different $\mathrm{K}_{\mathrm{Si}}$ values, comparing mean observations to mean model outputs for (a) Chla and (b) DSi concentrations. Vertical axes are relative depths, with a maximum depth of one.

1989; Eicken, 1992), would contribute but not be able to supply nutrients above seawater levels $\left(\mathrm{NO}_{3}{ }^{-}+\right.$ $\mathrm{NO}_{2}{ }^{-}, \mathrm{NH}_{4}{ }^{+}$, and $\mathrm{PO}_{4}{ }^{3}$; Figures 5 and 7). Similarly, surface flooding, which occurs when the snow-ice interface sinks below sea level, is virtually absent at Davis (snow depth is typically below $0.05 \mathrm{~m}$ ) and fails to explain observed nutrient concentrations. This suggests that a biogeochemical supply process is active for the nutrients that are above the TDL. A limitation of this study is the lack of baseline seawater data for establishing the TDLs: Ideally, they would be calculated from seawater in winter, when light and temperature minimize biological activity. Since 10-m seawater concentrations of $\mathrm{NO}_{3}{ }^{-}+\mathrm{NO}_{2}{ }^{-}=29.49 \pm 0.81, \mathrm{PO}_{4}{ }^{3-}$ $=2.03 \pm 0.05$, and $\mathrm{DSi}=51.86 \pm 3.60 \mu \mathrm{M}(n=6)$ were close to median late winter seawater values in the East Antarctic sector of 29, 2, and $60 \mu \mathrm{M}$, respectively (Becquevort et al., 2009), they were considered sufficient approximations for winter conditions.

In situ recycling processes within the sea-ice community could be partly responsible for replenishing nutrient supplies. Ammonium consistently above the TDL (Figure 5) suggests remineralization by bacteria (Arrigo et al., 1995; Grossmann et al., 1996) that is greater than consumption (assimilation + nitrification) at all depths. In Fripiat et al.'s (2017) compilation of Antarctic pack ice cores, $\mathrm{NH}_{4}{ }^{+}$was found to similarly accumulate-often at higher concentrations-at all depths during the spring. Nitrate, $\mathrm{NO}_{2}{ }^{-}$, and $\mathrm{PO}_{4}{ }^{3-}$ above the TDL in the bottom layer similarly point to remineralization, perhaps with organic matter and brine channel walls as favorable microenvironments for bacteria (Meiners et al., 2004). A well-established bacterial community is able to break down detritus, making nutrients bioavailable for new growth. We suggest that the resulting $\mathrm{NO}_{3}{ }^{-}+\mathrm{NO}_{2}{ }^{-}$and $\mathrm{PO}_{4}{ }^{3-}$ are additionally retained by adsorption in these microenvironments (Becquevort et al., 2009; Meiners \& Michel, 2017), preventing removal by physical exchanges. Although there is little evidence of adsorption for nitrogen in the form of $\mathrm{NO}_{3}{ }^{-}+\mathrm{NO}_{2}{ }^{-}, \mathrm{NH}_{4}{ }^{+}$is known to adsorb onto organic matter, especially the high pool of exopolymeric particles in sea ice (Becquevort et al., 2009). Oxidation then converts $\mathrm{NH}_{4}{ }^{+}$to $\mathrm{NO}_{2}{ }^{-}$and $\mathrm{NO}_{3}{ }^{-}$; nitrification has been shown to be significant in sea ice, especially in microbe-rich biofilms (Baer et al., 2015; Firth et al., 2016; Fripiat et al., 2014; Fripiat et al., 2015; Priscu et al., 1990). Though commonly overlooked, nutrient adsorption after bacterial remineralization is a plausible explanation for $\mathrm{NO}_{3}{ }^{-}+\mathrm{NO}_{2}{ }^{-}$and $\mathrm{PO}_{4}{ }^{3-}$ accumulation in the bottom of the sea ice.

Could brine-dwelling, heterotrophic protists and metozoans be driving the stable conditions? Their consumption of sea-ice algae could prevent increases in Chla, then playing a similar role to bacteria in returning inorganic nutrients to the sea ice. In a summer study at Davis, heterotrophic grazing was estimated to have consumed up to $25 \%$ of primary production (Archer et al., 1996). Although no quantitative communitycomposition measurements were made in our spring study, the ratio of POC:Chla was $49-313$ in the bottom ice and $4.06 \pm 3.07(n=6)$ in the $10-\mathrm{m}$ seawater sample. The ratio in sea ice is approximate, because POC and Chla were measured in separate cores at slightly different depths. For comparison, in late winter-early spring, East Antarctic pack ice had POC:Chla 219-248 and a median heterotroph to autotroph ratio of 0.03 (range $0.01-1.15$ ) with $<1 \%$ protozoa; seawater with POC:Chla 1,000 had a 8.5 heterotrophs to autotrophs ratio and $11 \%$ protozoa (Becquevort et al., 2009). Thus, while the POC:Chla in this study does imply a sizeable amount of non-chlorophyll containing matter, it does not necessarily indicate a large grazer population. Detritus and bacteria also contribute to POC and are necessary for the remineralization 
processes proposed earlier. Overall, van Leeuwe et al.'s (2018) compilation of cores found that heterotrophic grazers likely have only a small presence in sea ice. On average, heterotrophs have a $10 \%$ abundance $(S E M=$ 3, range $=0-91$ ) in Antarctic fast ice and are most dominant in early spring, when light availability and phototrophs are low (van Leeuwe et al., 2018). The lack of observational data prevents us from including them in the model. While grazing is outside of the scope of this study, food web interactions should be recognized as a phenomenon poorly constrained in sea ice. Even so, with the given POC:Chla data and knowledge of other fast ice systems, nutrient availability remains the most plausible control of sea-ice algal biomass.

The model and observations both suggest that $\mathrm{NO}_{3}{ }^{-}+\mathrm{NO}_{2}{ }^{-}$and $\mathrm{PO}_{4}{ }^{3-}$ concentrations are sufficient to sustain the high biomass observed in the bottom sea ice. While the model is limited in that its nutrient uptake follows the Redfield ratio, this assumption appears valid for nitrogen and phosphorus observed in the bottom ice (Figure 4). However, the DSi:N ratios in the bottom of the sea ice, where the majority of biomass was concentrated, were extremely low (Figure 4b). Observed DSi concentrations in the bottom ice were consistently below the TDL, and the model output also indicates DSi limitation (Figure 6f). Since nitrogen species and phosphate are above the TDL and seawater levels, we argue that DSi supply is the ultimate control of the system's evolution. This is consistent with a 3-D modeling study, in which Si limitation became more important relative to light and $\mathrm{N}$ limitation in the late Antarctic spring and summer (Saenz \& Arrigo, 2014). Furthermore, we found no evidence in the literature that DSi adsorbs onto organic matter in the same manner as $\mathrm{NH}_{4}{ }^{+}$and $\mathrm{PO}_{4}{ }^{3-}$. Limited physical exchange with seawater constrains DSi in a way that remineralization cannot compensate for. Hence, DSi supply and demand are critical aspects to examine in order to understand why model simulations tend to overestimate Chla and underestimate DSi as compared with observations (Figure 7).

\subsection{DSi Supply and Affinity}

Diatoms are the main users of $\mathrm{DSi}$, converting it to $\mathrm{bSiO}_{2}$ to build their cell wall frustules. Our observations that diatoms are the major primary producers in the basal fast ice are consistent with past studies at Davis, which primarily found Nitzschia frigida (McConville \& Wetherbee, 1983), E. kjellmanii, N. stellata, Thalassiosira australis, Berkeleya adeliense, Navicula glacei (Gibson et al., 1999), and other Entomoneis spp. (Archer, Leakey, Burkill, \& Sleigh, 1996). The dominance of pennate diatoms in the bottom ice has also been characterized in a compilation of over 300 sea-ice cores from the Arctic and Antarctic (van Leeuwe et al., 2018).

We propose that DSi is the most limiting nutrient for algal growth in the bottom ice. It remains unresolved why other algal groups or smaller, less-silicified diatoms are unable to take advantage of this, but bottom ice communities - in this study and in others-are consistently dominated by large diatoms (van Leeuwe et al., 2018). We also hypothesize that sea-ice diatoms require more DSi than pelagic diatoms. To come to this, we acted on three specific model features that may explain the discrepancies in observations of high Chla and low DSi in the bottom sea ice: (a) the silicon quota in organic matter (DSi:C ratio), (b) the dissolution and production rates of $\mathrm{bSiO}_{2}$, and (c) the affinity of sea-ice diatoms for DSi.

The DSi:C ratio $=0.11$ used in the model simulations is based on marine diatoms (Sarthou et al., 2005) and therefore not necessarily suited to the sea-ice environment. Sea-ice diatoms are frequently larger than pelagic diatoms (Arrigo et al., 2010), altering the surface area to volume ratio, while lower temperatures tend to increase silicification (Martin-Jezequel et al., 2000). However, changing DSi:C does not alter Chla and POC biomass because it affects $\mathrm{bSiO}_{2}$ dissolution and DSi uptake in a similar way (Figures $8 \mathrm{a}$ and $8 \mathrm{~b}$ ). The increase in DSi reflects the higher amount of DSi implicitly stored in organic matter when using a higher DSi:C. It should be noted that on the last day, DSi:C $=0.95$ overpredicts DSi, which may increase with time. In the end, there is no reason to change our DSi:C quota in sea ice as compared to pelagic diatoms.

In sea ice, the dissolution of $\mathrm{bSiO}_{2}$ is likely the major biological source of DSi (Fripiat, Tison, et al., 2014). An accumulated bacterial population (Deming, 2010) degrades the protective organic matrix around the frustules, exposing them to the surrounding undersaturated brine environment (Bidle \& Azam, 1999). Even so, $\mathrm{bSiO}_{2}$ dissolution is a slow process, particularly under cold conditions, and is made possible by substantially higher residence times for detritus in the brine network compared to in the ocean (Fripiat et al., 2017). In Antarctic pack ice, estimates of the dissolution to production ratio range from 0.4 to 0.9 (Fripiat, Tison, et al., 2014). We tested ratios between 0.0007 and 0.07 by changing $\mu_{\max }$ (production) relative to the 

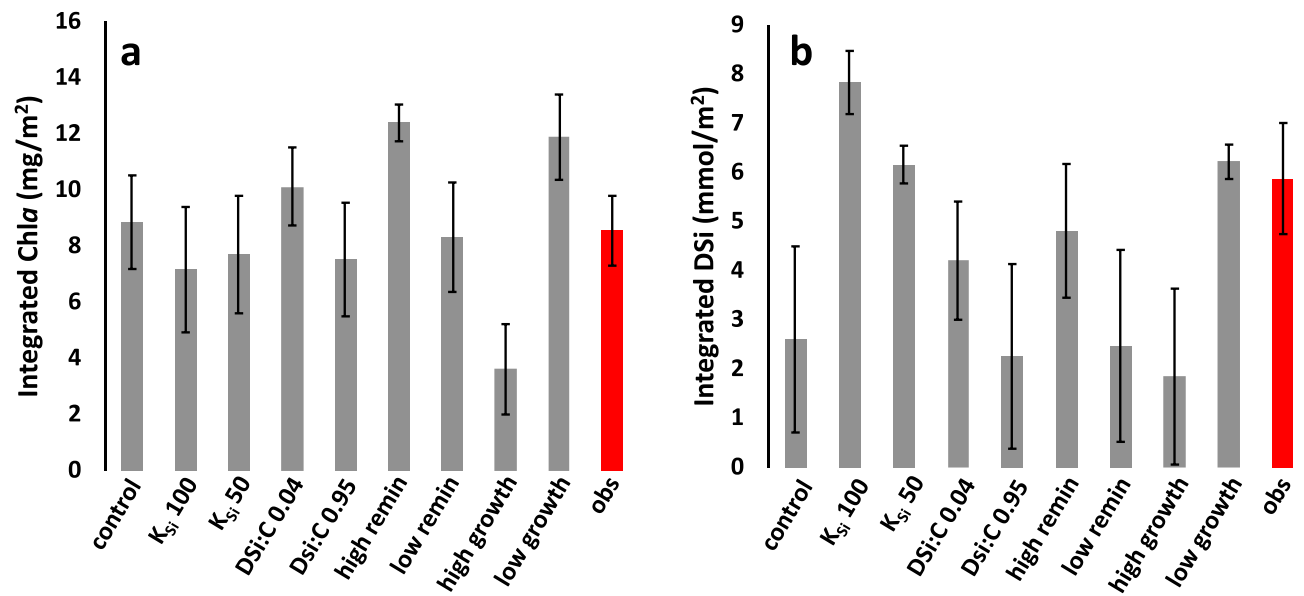

Figure 12. Depth-integrated observations (red, $n=6$ ) and model outputs (gray, $n=385$ ) averaged over the course of the time series for (a) DSi and (b) Chla concentrations. Error bars indicate standard deviation.

remineralization (dissolution) rate. With respect to the bottom ice, results show that neither the process of frustule dissolution nor production can fully explain the observed DSi and Chla profiles during this time series (Figures 9 and 10). However, in the upper sea ice, a lower $\mu_{\max }$ better simulated DSi concentration (Figure 10b), consistent with the fact that these communities are mainly flagellates and Phaeocystis spp. (van Leeuwe et al., 2018) that do not uptake DSi. At Davis in particular, the interior ice community tends to be dominated by Gymnodinium sp., a small dinoflagellate, and autotrophs $<20 \mu \mathrm{m}$ long (Archer, Leakey, Burkill, \& Sleigh, 1996). Since the model is based on pelagic diatoms, a slower growth rate in the upper ice would better reproduce the lack of DSi use, even though it does not correctly represent the growth of non-silicified algae. As flagellates make up 76\%, 65\%, and 31\% of surface, interior, and bottom ice communities, respectively, in Antarctic fast ice (van Leeuwe et al., 2018), future studies should account for different types of phytoplankton assemblages across the ice cover, for example, following the approaches of Tedesco et al. (2012) and Aumont et al. (2015).

Although there are no current studies that quantify sea-ice diatoms' DSi requirement for growth, the model predicts that sea-ice diatoms may require one order of magnitude more DSi than observed for cultured pelagic diatoms (i.e., average $\mathrm{K}_{\mathrm{Si}}=3.9 \mu \mathrm{M}$; Sarthou et al., 2005). Comparing all of the model parameterizations, $\mathrm{K}_{\mathrm{Si}}=50 \mu \mathrm{M}$ is best able to match depth-integrated observations of both DSi and Chla, while most sensitivity runs only reproduce the Chla stocks well (e.g., the control, low remineralization, and DSi:C $=0.95$ runs, Figure 12). The kinetics of DSi uptake may be related to the type and expression of DSi transporter in the cells, which is not only species dependent but may also change during the course of cell wall synthesis (Martin-Jezequel et al., 2000). In general, the kinetics of diatoms typical at Davis, including the genuses Entomoneis and Nitzchia (Archer, Leakey, Burkill, \& Sleigh, 1996; Gibson et al., 1999; McConville \& Wetherbee, 1983), are poorly, if at all, characterized (Martin-Jezequel et al., 2000). Importantly, cultures of diatoms collected from Antarctic waters reported $\mathrm{K}_{\mathrm{Si}}$ one to two orders of magnitude higher than diatoms from temperate or tropical oceans (Jacques, 1983; Sommer, 1986; Sommer, 1991), though field-based experiments question those high $\mathrm{K}_{\mathrm{Si}}$ values (Nelson \& Treguer, 1992). Some Antarctic sea ice models used $\mathrm{K}_{\mathrm{Si}}=60$ $\mu \mathrm{M}$ (Arrigo \& Sullivan, 1994; Saenz \& Arrigo, 2012, 2014), based on unpublished sea-ice algae data from C. W. Sullivan (referenced in Arrigo et al., 1993). In the end, Arrigo et al. (1993) concluded that light availability was more important than DSi as a control on the fast ice system at McMurdo Sound in the Ross Sea. However, at sites like Davis or in 3-D models like in Saenz and Arrigo (2014), a much lower affinity for DSi would cause sea-ice diatoms to experience limitation at relatively high ambient DSi concentrations, including the brine-normalized concentrations observed in this study. Based on our model simulation with $\mathrm{K}_{\mathrm{Si}}=50 \mu \mathrm{M}$, this hypothesis may well be true in sea ice and calls for a focused investigation on DSi uptake kinetics for cultured and natural assemblages of sea-ice diatoms. Meanwhile, this information might be used in following attempts to model the large-scale impact of sea-ice primary productivity on the global carbon cycle, in the likes of Castellani et al. (2017). 


\section{Conclusion}

This study presents and discusses a 17-day time series of biogeochemical sea-ice observations from Davis, East Antarctica, together with one-dimensional sea-ice modeling, to examine fast ice processes in late austral spring. Ice temperature, salinity, and brine volume showed depth-wise and temporal patterns characteristic of first-year sea ice. With initialization using the first day of observations and little temporal evolution, model outputs of ice physics matched observations fairly well. The co-occurrence of high nutrients and high chlorophyll indicates sufficient sources of most nutrients. Sea ice was replenished with $\mathrm{NO}_{3}{ }^{-}+\mathrm{NO}_{2}{ }^{-}, \mathrm{PO}_{4}{ }^{3-}$, and $\mathrm{NH}_{4}{ }^{+}$, but our observations and model simulations suggest that DSi was limiting. Bacterial remineralization and adsorption within sea ice may constitute the main source of $\mathrm{NO}_{3}{ }^{-}+\mathrm{NO}_{2}{ }^{-}, \mathrm{PO}_{4}{ }^{3-}$, and $\mathrm{NH}_{4}{ }^{+}$. Comparisons between model simulations and observations suggest that models likely need to account for the distinct compositions of algal communities at different depths in the ice. We further propose that some sea-ice diatoms may have a much lower affinity for DSi than pelagic diatoms. Future research should include quantification of DSi cellular requirements by sea-ice algae, grazing, the role of biofilms in retaining organic matter and nutrients, and modeling ocean-ice biogeochemical interactions.

\section{Conflict of Interest}

The authors declare they have no competing interest of any kind with this research and the publication of this manuscript.

\section{Acknowledgments}

We thank Phillip Assmy for his help with identifying ice algae species. Thank you to the two anonymous reviewers for their comments which helped improve this paper. This work was co-funded by the Australian Government Cooperative Research Centres Programme through the Antarctic Climate \& Ecosystems (ACECRC) Carbon program 2.1, the Australian Antarctic Science (AAS) project no. 4291, and the Australian Research Council's Special Research Initiative for Antarctic Gateway Partnership (Project ID SR140300001). Stephanie Lim was supported by the Rainforest, Reef, and Cultural Ecology, School for International Training (SIT) Study Abroad program. The data presented in this paper are available under Duprat (2019, updated 2019).

\section{References}

Archer, S., Leakey, R., Burkill, P., \& Sleigh, M. (1996). Microbial dynamics in coastal waters of East Antarctica: Herbivory by heterotrophic dinoflagellates. Marine Ecology Progress Series, 139, 239-255. https://doi.org/10.3354/meps139239

Archer, S. D., Leakey, R. J. G., Burkill, P. H., Sleigh, M. A., \& Appleby, C. J. (1996). Microbial ecology of sea ice at a coastal Antarctic site: Community composition, biomass and temporal change. Marine Ecology Progress Series, 135, 179-195. https://doi.org/10.3354/ meps135179

Arrigo, K. R., Dieckmann, G., Gosselin, M., Robinson, D. H., Fritsen, C. H., \& Sullivan, C. W. (1995). High resolution study of the platelet ice ecosystem in McMurdo Sound, Antarctica: Biomass, nutrient, and production profiles within a dense microalgal bloom. Marine Ecology Progress Series, 127, 255-268. https://doi.org/10.2307/24855138

Arrigo, K. R., Kremer, J. N., \& Sullivan, C. W. (1993). A simulated Antarctic ast ice ecosystem. Journal of Geophysical Research, 98(C4), 6929-6946. https://doi.org/10.1029/93JC00141

Arrigo, K. R., Mock, T., \& Lizotte, M. P. (2010). Primary producers and sea ice. In Sea ice, (2nd ed.pp. 283-325). Oxford, UK: WileyBlackwell. https://doi.org/10.1002/9781444317145.ch8

Arrigo, K. R., Robinson, D. H., Dunbar, R. B., Leventer, A. R., \& Lizotte, M. P. (2003). Physical control of chlorophyll $a$, POC, and TPN distributions in the pack ice of the Ross Sea, Antarctica. Journal of Geophysical Research, 108(C10), 3316. https://doi.org/10.1029/ 2001JC001138

Arrigo, K. R., \& Sullivan, C. W. (1994). A high resolution bio-optical model of microalgal growth: Tests using sea-ice algal community timeseries data. Limnology and Oceanography, 39(3), 609-631. https://doi.org/10.4319/lo.1994.39.3.0609

Arrigo, K. R., Sullivan, C. W., \& Kremer, J. N. (1991). A bio-optical model of Antarctic sea ice. Journal of Geophysical Research, 96(C6), 10581. https://doi.org/10.1029/91JC00455

Arrigo, K. R., Worthen, D. L., Lizotte, M. P., Dixon, P., \& Dieckmann, G. (1997). Primary production in Antarctic sea ice. Science, 276(5311), 394-397. https://doi.org/10.1126/SCIENCE.276.5311.394

Aumont, O., Ethé, C., Tagliabue, A., Bopp, L., \& Gehlen, M. (2015). PISCES-v2: An ocean biogeochemical model for carbon and ecosystem studies. Geoscientific Model Development, 8(8), 2465-2513. https://doi.org/10.5194/gmd-8-2465-2015

Baer, S. E., Connelly, T. L., \& Bronk, D. A. (2015). Nitrogen uptake dynamics in landfast sea ice of the Chukchi Sea. Polar Biology, 38(6), 781-797. https://doi.org/10.1007/s00300-014-1639-y

Barnes-Keoghan, I. (2000). Antarctic Climate Data Collected by Australian Agencies. Australian Antarctic Data Centre - CAASM Metadata. https://data.aad.gov.au/metadata/records/Antarctic Meteorology

Becquevort, S., Dumont, I., Tison, J.-L., Lannuzel, D., Sauvée, M.-L., Chou, L., \& Schoemann, V. (2009). Biogeochemistry and microbial community composition in sea ice and underlying seawater off East Antarctica during early spring. Polar Biology, 32(6), 879-895. https://doi.org/10.1007/s00300-009-0589-2

Bidle, K. D., \& Azam, F. (1999). Accelerated dissolution of diatom silica by marine bacterial assemblages. Nature, 397(6719), 508-512. https://doi.org/10.1038/17351

Boyd, P. W., Arrigo, K. R., Strzepek, R., \& van Dijken, G. L. (2012). Mapping phytoplankton iron utilization: Insights into Southern Ocean supply mechanisms. Journal of Geophysical Research, 117, C06009. https://doi.org/10.1029/2011JC007726

Boyd, P. W., Watson, A. J., Law, C. S., Abraham, E. R., Trull, T., Murdoch, R., et al. (2000). A mesoscale phytoplankton bloom in the polar Southern Ocean stimulated by iron fertilization. Nature, 407(6805), 695-702. https://doi.org/10.1038/35037500

Brzezinski, M. A. (1985). The Si:C:N ratio of marine diatoms: Interspecific variability and the effect of some environmental variables. Journal of Phycology, 21(3), 347-357. https://doi.org/10.1111/j.0022-3646.1985.00347.x

Castellani, G., Losch, M., Lange, B. A., \& Flores, H. (2017). Modeling Arctic sea-ice algae: Physical drivers of spatial distribution and algae phenology. Journal of Geophysical Research: Oceans, 122, 7466-7487. https://doi.org/10.1002/2017JC012828

Cota, G., Legendre, L., Gosselin, M., \& Ingram, R. (1991). Ecology of bottom ice algae: I. Environmental controls and variability. Journal of Marine Systems, 2(3-4), 257-277. https://doi.org/10.1016/0924-7963(91)90036-T 
Cota, G. F., \& Horne, E. P. W. (1989). Physical control of arctic ice algal production. Marine Ecology Progress Series, 52, 111-121. https://doi. org/10.3354/meps052111

Cota, G. F., Prinsenberg, S. J., Bennett, E. B., Loder, J. W., Lewis, M. R., Anning, J. L., et al. (1987). Nutrient fluxes during extended blooms of Arctic ice algae. Journal of Geophysical Research, 92(C2), 1951. https://doi.org/10.1029/JC092iC02p01951

Cox, G. F. N., \& Weeks, W. F. (1983). Equation for determining the gas and brine volumes in sea-ice samples. Journal of Glaciology, 29(102), 306-316. https://doi.org/10.1017/S0022143000008364

Deming, J. W. (2010). Sea ice bacteria and viruses. In Sea ice, (2nd ed.pp. 247-282). Oxford, UK: Wiley-Blackwell. https://doi.org/10.1002/ 9781444317145.ch7

Doney, S. C., Glover, D. M., \& Najjar, R. G. (1996). A new coupled, one-dimensional biological-physical model for the upper ocean: Applications to the JGOFS Bermuda Atlantic Time-series Study (BATS) site. Deep Sea Research Part II: Topical Studies in Oceanography, 43(2-3), 591-624. https://doi.org/10.1016/0967-0645(95)00104-2

Duarte, P., Meyer, A., Olsen, L. M., Kauko, H. M., Assmy, P., Rösel, A., et al. (2017). Sea ice thermohaline dynamics and biogeochemistry in the Arctic Ocean: Empirical and model results. Journal of Geophysical Research: Biogeosciences, 122, 1632-1654. https://doi.org/10.1002/ 2016JG003660

Duprat, L. (2019, updated 2019). Davis sea ice Nov. 2016. Australian Antarctic Data Centre https://doi.org/10.26179/5cad74d6a3179

Eicken, H. (1992). Salinity profiles of Antarctic sea ice: Field data and model results. Journal of Geophysical Research, 97(C10), 15545. https://doi.org/10.1029/92JC01588

Fetterer, F., K. Knowles, W. Meier, M. Savoie, and A. K. Windnagel. (2017). Sea Ice Index, version 3. Boulder, Colorado USA. NSIDC: National Snow and Ice Data Center. https://doi.org/10.7265/N5K072F8.

Firth, E., Carpenter, S. D., Sørensen, H. L., Collins, R. E., \& Deming, J. W. (2016). Bacterial use of choline to tolerate salinity shifts in sea-ice brines. Elementa: Science of the Anthropocene, 4(0), 120. https://doi.org/10.12952/journal.elementa.000120

Fripiat, F., Meiners, K. M., Vancoppenolle, M., Papadimitriou, S., Thomas, D. N., Ackley, S. F., et al. (2017). Macro-nutrient concentrations in Antarctic pack ice: Overall patterns and overlooked processes. Elementa: Science of the Anthropocene, 5(0), 13. https://doi.org/ 10.1525/elementa.217

Fripiat, F., Sigman, D. M., Fawcett, S. E., Rafter, P. A., Weigand, M. A., \& Tison, J.-L. (2014). New insights into sea ice nitrogen biogeochemical dynamics from the nitrogen isotopes. Global Biogeochemical Cycles, 28, 115-130. https://doi.org/10.1002/2013GB004729

Fripiat, F., Sigman, D. M., Massé, G., \& Tison, J.-L. (2015). High turnover rates indicated by changes in the fixed N forms and their stable isotopes in Antarctic landfast sea ice. Journal of Geophysical Research: Oceans, 120, 3079-3097. https://doi.org/10.1002/2014JC010583

Fripiat, F., Tison, J. L., André, L., Notz, D., \& Delille, B. (2014). Biogenic silica recycling in sea ice inferred from Si-isotopes: Constraints from Arctic winter first-year sea ice. Biogeochemistry, 119(1-3), 25-33. https://doi.org/10.1007/s10533-013-9911-8

Gibson, J. A. E., Trull, T., Nichols, P. D., Summons, R. E., \& McMinn, A. (1999). Sedimentation of ${ }^{13}$ C-rich organic matter from Antarctic sea-ice algae: A potential indicator of past sea-ice extent. Geology, 27(4), 331-334.

Golden, K. M., Ackley, S. F., \& Lytle, V. I. (1998). The percolation phase transition in sea ice. Science, 282(5397), 2238-2241. https://doi.org/ $10.1126 /$ science. 282.5397 .2238

Gradinger, R. (2009). Sea-ice algae: Major contributors to primary production and algal biomass in the Chukchi and Beaufort Seas during May/June 2002. Deep Sea Research Part II: Topical Studies in Oceanography, 56(17), 1201-1212. https://doi.org/10.1016/J DSR2.2008.10.016

Grossmann, S., Lochte, K., \& Scharek, R. (1996). Algal and bacterial processes in platelet ice during late austral summer. Polar Biology, 16(8), 623-633. https://doi.org/10.1007/BF02329060

Grotti, M., Soggia, F., Ianni, C., \& Frache, R. (2005). Trace metals distributions in coastal sea ice of Terra Nova Bay, Ross Sea, Antarctica. Antarctic Science, 17(2), 289-300. https://doi.org/10.1017/S0954102005002695

Hansen, H. P., \& Koroleff, F. (1999). Determination of nutrients. In K. Grasshoff, K. Kremling, \& M. Ehrhardt (Eds.), Methods of seawater analysis (3rd ed., pp. 159-228). Weinheim, Germany: Wiley-VCH Verlag GmbH. https://doi.org/10.1002/9783527613984.ch10

Holm-Hansen, O., Lorenzen, C. J., Holmes, R. W., \& Strickland, J. D. H. (1965). Fluorometric determination of chlorophyll. ICES Journal of Marine Science, 30(1), 3-15. https://doi.org/10.1093/icesjms/30.1.3

Jacques, G. (1983). Some ecophysiological aspects of the Antarctic phytoplankton. Polar Biology, 2(1), 27-33. https://doi.org/10.1007/ BF00258282

Lannuzel, D., Vancoppenolle, M., van der Merwe, P., de Jong, J., Meiners, K. M., Grotti, M., et al. (2016). Iron in sea ice: Review and new insights. Elementa: Science of the Anthropocene, 4(0), 130. https://doi.org/10.12952/journal.elementa.000130

Lavoie, D., Denman, K., \& Michel, C. (2005). Modeling ice algal growth and decline in a seasonally ice-covered region of the Arctic (Resolute Passage, Canadian Archipelago). Journal of Geophysical Research, 110(C11), C11009. https://doi.org/10.1029/ 2005JC002922

Legendre, L., Ackley, S. F., Dieckmann, G. S., Gulliksen, B., Horner, R., Hoshiai, T., et al. (1992). Ecology of sea ice biota. Polar Biology, 12 (3-4), 429-444. https://doi.org/10.1007/BF00243114

Lorenzen, C. J. (1966). A method for the continuous measurement of in vivo chlorophyll concentration. Deep Sea Research and Oceanographic Abstracts, 13(2), 223-227. https://doi.org/10.1016/0011-7471(66)91102-8

Manabe, S., \& Stouffer, R. J. (1980). Sensitivity of a global climate model to an increase of $\mathrm{CO}_{2}$ concentration in the atmosphere. Journal of Geophysical Research, 85(C10), 5529-5554. https://doi.org/10.1029/JC085iC10p05529

Martin, J. H. (1990). Glacial-interglacial $\mathrm{CO}_{2}$ change: The iron hypothesis. Paleoceanography, 5(1), 1-13. https://doi.org/10.1029/ PA005i001p00001

Martin-Jezequel, V., Hildebrand, M., \& Brzezinski, M. A. (2000). Silicon metabolism in diatoms: Implications for growth. Journal of Phycology, 36(5), 821-840. https://doi.org/10.1046/j.1529-8817.2000.00019.x

McConville, M. J., \& Wetherbee, R. (1983). The bottom-ice microalgal community from annual ice in the inshore waters of East Antarctica. Journal of Phycology, 19(4), 431-439. https://doi.org/10.1111/j.0022-3646.1983.00431.x

Meiners, K. M., Brinkmeyer, R., Granskog, M. A., \& Lindfors, A. (2004). Abundance, size distribution and bacterial colonization of exopolymer particles in Antarctic sea ice (Bellingshausen Sea). Aquatic Microbial Ecology, 35, 283-296. https://doi.org/10.3354/ ame035283

Meiners, K. M., \& Michel, C. (2017). Dynamics of nutrients, dissolved organic matter and exopolymers in sea ice. In Sea Ice, (3rd ed.pp. 415-432). Chichester, UK: John Wiley \& Sons, Ltd. https://doi.org/10.1002/9781118778371.ch17

Meiners, K. M., Vancoppenolle, M., Carnat, G., Castellani, G., Delille, B., Delille, D., et al. (2018). Chlorophyll- $a$ in Antarctic landfast sea ice: A first synthesis of historical ice core data. Journal of Geophysical Research: Oceans, 123, 8444-8459. https://doi.org/10.1029/ 2018JC014245 
Moreau, S., Kaartokallio, H., Vancoppenolle, M., Zhou, J., Kotovitch, M., Dieckmann, G. S., et al. (2015). Assessing the O2 budget under sea ice: An experimental and modelling approach. Elementa: Science of the Anthropocene, 3. https://doi.org/10.12952/journal. elementa.000080

Moreau, S., Vancoppenolle, M., Delille, B., Tison, J.-L., Zhou, J., Kotovitch, M., et al. (2015). Drivers of inorganic carbon dynamics in firstyear sea ice: A model study. Journal of Geophysical Research: Oceans, 120, 471-495. https://doi.org/10.1002/2014JC010388

Moreau, S., Vancoppenolle, M., Zhou, J., Tison, J.-L., Delille, B., \& Goosse, H. (2014). Modelling argon dynamics in first-year sea ice. Ocean Modelling, 73, 1-18. https://doi.org/10.1016/J.OCEMOD.2013.10.004

Nelson, D. M., \& Treguer, P. (1992). Role of silicon as a limiting nutrient to Antarctic diatoms: Evidence from kinetic studies in the Ross Sea ice-edge zone. Marine Ecology Progress Series, 80, 255-264. https://doi.org/10.3354/meps080255

Petrich, C., \& Eicken, H. (2010). Growth, structure and properties of sea ice. In Sea Ice (pp. 23-77). Oxford, UK: Wiley-Blackwell. https:// doi.org/10.1002/9781444317145.ch2

Priscu, J. C., Downes, M. T., Priscu, L. R., Palmisano, A. C., \& Sullivan, C. W. (1990). Dynamics of ammonium oxidizer activity and nitrous oxide $\left(\mathrm{N}_{2} \mathrm{O}\right)$ within and beneath Antarctic sea ice. Marine Ecology Progress Series, 62, 37-46. https://doi.org/10.3354/meps062037

Redfield, A. C., Ketchum, B. H., \& Richards, F. A. (1963). The influence of organisms on the composition of seawater. In M. N. Hill (Ed.), The sea: Ideas and observations on progress in the study of the seas, (pp. 26-77). New York: Interscience Publishers.

Reeburgh, W. S. (1984). Fluxes associated with brine motion in growing sea ice. Polar Biology, 3(1), 29-33. https://doi.org/10.1007/ BF00265564

Rintala, J.-M., Piiparinen, J., Blomster, J., Majaneva, M., Müller, S., Uusikivi, J., \& Autio, R. (2014). Fast direct melting of brackish sea-ice samples results in biologically more accurate results than slow buffered melting. Polar Biology, 37(12), 1811-1822. https://doi.org/ 10.1007/s00300-014-1563-1

Sabine, C. L., Feely, R. A., Gruber, N., Key, R. M., Lee, K., Bullister, J. L., et al. (2004). The oceanic sink for anthropogenic $\mathrm{CO}_{2}$. Science, 305 (5682), 367-371. https://doi.org/10.1126/science.1097403

Saenz, B. T., \& Arrigo, K. R. (2012). Simulation of a sea ice ecosystem using a hybrid model for slush layer desalination. Journal of Geophysical Research, 117, C05007. https://doi.org/10.1029/2011JC007544

Saenz, B. T., \& Arrigo, K. R. (2014). Annual primary production in Antarctic sea ice during 2005-2006 from a sea ice state estimate. Journal of Geophysical Research: Oceans, 119, 3645-3678. https://doi.org/10.1002/2013JC009677

Sarthou, G., Timmermans, K. R., Blain, S., \& Tréguer, P. (2005). Growth physiology and fate of diatoms in the ocean: A review. Journal of Sea Research, 53(1-2), 25-42. https://doi.org/10.1016/j.seares.2004.01.007

Sedwick, P. N., Edwards, P. R., Mackey, D. J., Griffiths, F. B., \& Parslow, J. S. (1997). Iron and manganese in surface waters of the Australian subantarctic region. Deep Sea Research Part I: Oceanographic Research Papers, 44(7), 1239-1253. https://doi.org/10.1016/S0967-0637(97) 00021-6

Sommer, U. (1986). Nitrate- and silicate-competition among Antarctic phytoplankton. Marine Biology, 91(3), 345-351. https://doi.org/ $10.1007 / \mathrm{BF} 00428628$

Sommer, U. (1991). Comparative nutrient status and competitive interactions of two Antarctic diatoms (Corethron criophilum and Thalassiosira antarctica). Journal of Plankton Research, 13(1), 61-75. https://doi.org/10.1093/plankt/13.1.61

Steiner, N., Deal, C., Lannuzel, D., Lavoie, D., Massonnet, F., Miller, L. A., et al. (2016). What sea-ice biogeochemical modellers need from observers. Elementa: Science of the Anthropocene, 4(0), 84. https://doi.org/10.12952/journal.elementa.000084

Swadling, K. M., McKinnon, A. D., De'ath, G., \& Gibson, J. A. E. (2004). Life cycle plasticity and differential growth and development in marine and lacustrine populations of an Antarctic copepod. Limnology and Oceanography, 49(3), 644-655. https://doi.org/10.4319/ lo.2004.49.3.0644

Tedesco, L., Vichi, M., Haapala, J., \& Stipa, T. (2010). A dynamic Biologically Active Layer for numerical studies of the sea ice ecosystem. Ocean Modelling, 35(1-2), 89-104. https://doi.org/10.1016/J.OCEMOD.2010.06.008

Tedesco, L., Vichi, M., \& Thomas, D. N. (2012). Process studies on the ecological coupling between sea ice algae and phytoplankton. Ecological Modelling, 226, 120-138. https://doi.org/10.1016/J.ECOLMODEL.2011.11.011

Thomas, D. N., Papadimitriou, S., \& Michel, C. (2010). Biogeochemistry of sea ice. In Sea ice, (2nd ed.pp. 425-467). Oxford, UK: WileyBlackwell. https://doi.org/10.1002/9781444317145.ch12

van der Merwe, P., Lannuzel, D., Bowie, A. R., \& Meiners, K. M. (2011). High temporal resolution observations of spring fast ice melt and seawater iron enrichment in East Antarctica. Journal of Geophysical Research, 116, G03017. https://doi.org/10.1029/2010JG001628

van der Merwe, P., Lannuzel, D., Nichols, C. A. M., Meiners, K., Heil, P., Norman, L., et al. (2009). Biogeochemical observations during the winter-spring transition in East Antarctic sea ice: Evidence of iron and exopolysaccharide controls. Marine Chemistry, 115(3-4), 163-175. https://doi.org/10.1016/J.MARCHEM.2009.08.001

van Leeuwe, M., Tedesco, L., Arrigo, K. R., Assmy, P., Campbell, K., Meiners, K. M., et al. (2018). Microalgal community structure and primary production in Arctic and Antarctic sea ice: A synthesis. Elementa: Science of the Anthropocene, 6(1). https://doi.org/10.1525/ elementa.267

Vancoppenolle, M., Goosse, H., de Montety, A., Fichefet, T., Tremblay, B., \& Tison, J.-L. (2010). Modeling brine and nutrient dynamics in Antarctic sea ice: The case of dissolved silica. Journal of Geophysical Research, 115, C02005. https://doi.org/10.1029/2009JC005369

Vancoppenolle, M., \& Tedesco, L. (2017). Numerical models of sea ice biogeochemistry. In D. N. Thomas (Ed.), Sea ice, (3rd ed.pp. 492-515). Chichester, UK: John Wiley \& Sons, Ltd. https://doi.org/10.1002/9781118778371.ch20

Weeks, W. F., \& Hibler, W. D. (2010). On sea ice. University of Alaska Press. 